\title{
SUSTAINABLE RURAL DEVELOPMENT REQUIRES VALUE-ADDED ACTIVITIES LINKED WITH COMPARATIVE ADVANTAGE: THE CASE OF THE CATALAN PYRENEES
}

\author{
Antoni F. Tulla ${ }^{1}$
}

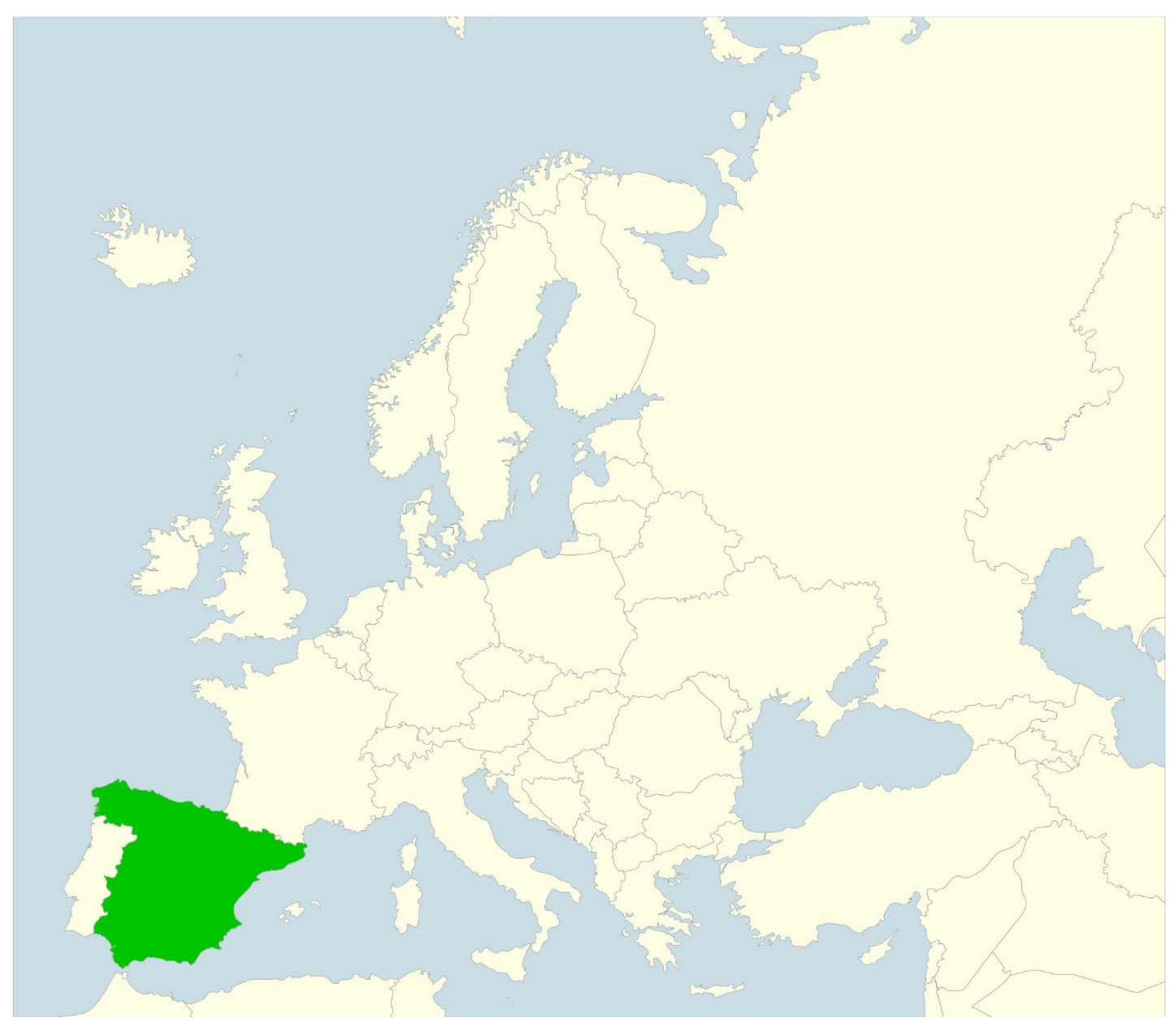

\footnotetext{
${ }^{1}$ Antoni Francesc Tulla Pujol, emeritus professor of human geography at the Universitat Autònoma de Barcelona, e-mail: Antoni.tulla@uab.cat; ORCID: 0000-0003-0937-3252
} 
Abstract: In a peripheral rural area like the Pyrenees, it is necessary to promote local resources, which can be converted in value-added activities with comparative advantages in relation with other areas. The Comparative Advantage Theory and Second-Best Option (SBO) methodology are presented here. Each local territory can develop activities or services, even though there are other places that may be more suitable for them, when these are the best specialization option for this territory. The idea of SBO methodology means engaging in activities that make it possible to achieve a comparative advantage. Four cases are discussed: a) transformation of dairy products into competitive value-added commodities; b) promotion of extensive cattle farming based on local natural grass feed; c) development of value-added tourist activities linked to local landscape; and d) planning value-added cultural activities related with cultural heritage.

Key words: Catalan Pyrenees, Comparative advantage, Rural development, Second-best option, Sustainability, Value added

Resum: El desenvolupament rural sostenible requereix activitats de valor afegit relacionades amb l'avantatge comparatiu. L'exemple del Pirineu Català. $A$ la perifèria rural com els Pirineus cal promoure recursos locals que es poden convertir en activitats de valor afegit, per tenir avantatges comparatius en relació amb altres àrees. Presentem la Teoria de l'avantatge comparatiu i la metodologia de la segona millor opció (SMO). Cada territori local pot desenvolupar activitats o serveis, fins i tot si hi ha altres territoris més adequats per als mateixos, quan és la millor especialització per a aquest territori. L'existència d'una "SMO" significa realitzar algunes activitats que permetin obtenir un avantatge comparatiu. Expliquem quatre casos: a) la transformació de productes lactis en uns de valor afegit competitiu; b) promoció de bestiar extensiu basat en pastures d'herba natural; c) desenvolupament d'activitats turístiques de valor afegit vinculades al paisatge natural; i d) les activitats culturals de valor afegit relacionades amb el patrimoni cultural.

Paraules clau: Avantatge comparatiu, Desenvolupament rural, Pirineu Català, Segona millor opció, Sostenibilitat, Valor Afegit

\section{Introduction}

The Catalan Pyrenees, also known as the High Pyrenees and Aran (HPA), is Catalonia's most mountainous region. ${ }^{2}$ As agriculture was modernized in the zone, a large part of its population was expelled to urban and industrial areas. With the crisis of productivist agriculture in the twentyfirst century, part of the HPA population has returned and the economy has since recovered.

The existence of protected natural areas (PNA), occupying $47 \%$ of the HPA (Figure 1) shows the benefits brought by naturbanization (Pallarès-Blanch et al., 2014) and multifunctionality (Zasada, 2011) in this recovery process. Agriculture also has environmental functions and hence can become a strategic sector in the PNA environment, although it will hardly be able to compete in international markets. Local consumption and products are encouraged (farm to table, slow food, $\mathrm{km}$. 0, etc.). This new territorial strategy is supported by EU objectives like promotion of renewable energies, conservation of biodiversity, conservation of the landscape, and the fight against climate change.

\footnotetext{
${ }^{2}$ Llei 23/1983 de Política Territorial (Article 12) and Llei 1/1995 del Pla Territorial General de Catalunya (Article 2), delimit planning regions by producing partial territorial plans such as those for the HPA.
} 


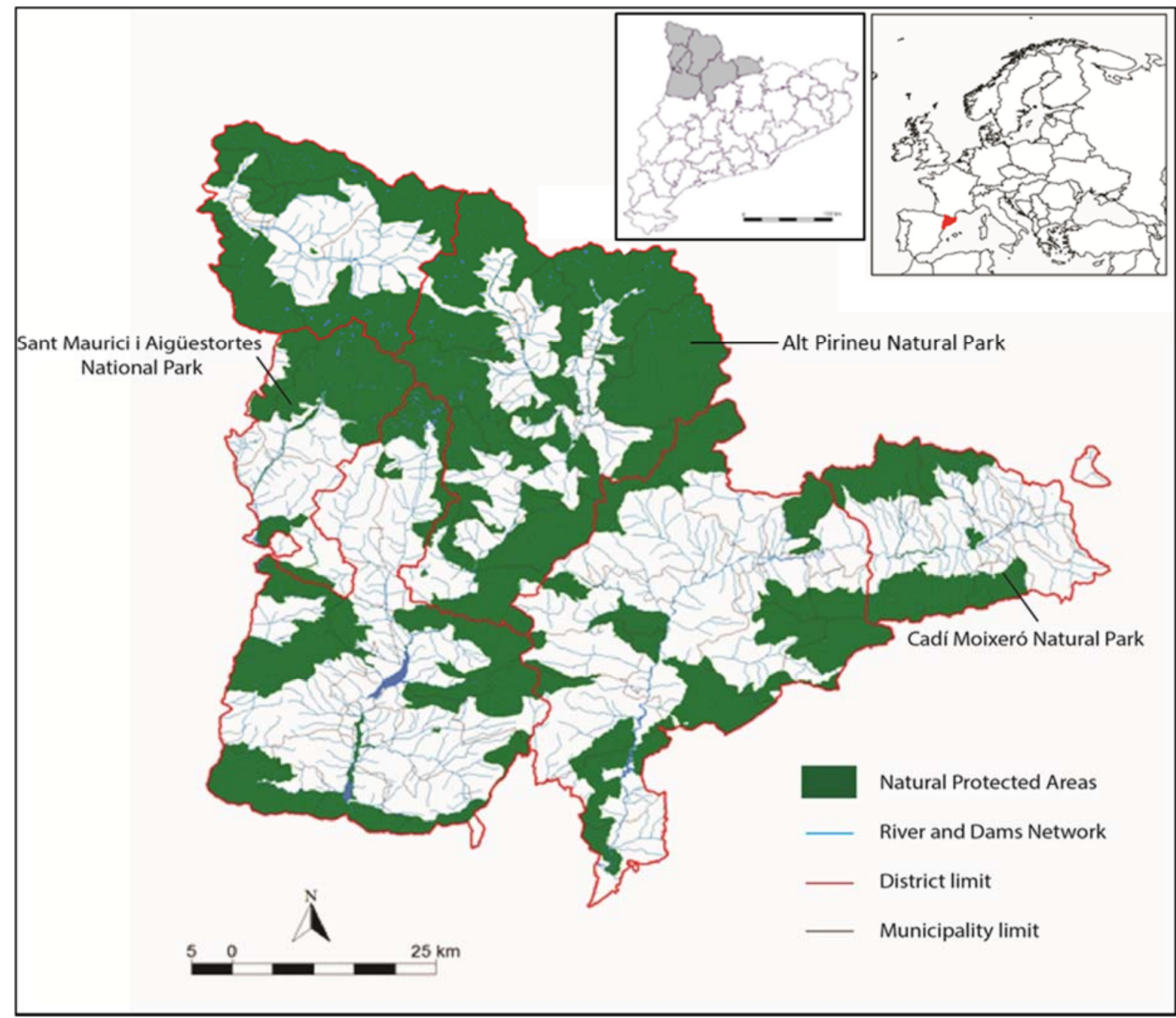

Fig 1. Alt Pirineu i Aran (APiA) Planning Region: Protected Natural Spaces. Source: Territory and Sustainability Department. Generalitat de Catalunya (2011) and A. F. Tulla

Two migratory flows in opposite directions have recently occurred in this region of the Pyrenees. Until 1991, there was constant gradual migration to urban areas "emptying the territory" down to a minimum of 61,954 inhabitants. However, since 2011 , new immigrants have accounted for $15 \%$ of the total population, which reached a peak of 77,189 inhabitants. Then, with the onset of the economic crisis in 2008, it once again fell to 71,637 in $2017^{3}$.

Economic and demographic recovery of some mountain regions in the sphere of influence of urban areas has been achieved through the comparative advantage of certain activities with added value, among them, processing and marketing of dairy products (Tulla et al., 2009), promotion of extensive cattle farming based on local natural grass feed (Eychenne, 2008), and the development of value-added cultural activities related to cultural heritage and social life (Throsby, 2001), as well as by means of spatial loyalty among the economic agents and the social aspects of each territorial area (Pallarès-Barberà et al., 2004). One example of the landscape can be seen in Figure 2.

\footnotetext{
${ }^{3}$ The population figures for the HPA region, with an area of 5,775.5 sq. km, show the following evolution: 30,066 (1717), 58,174 (1787), 107,627 (1860), 74,186 (1900), 75,582 (1950), 65,917 (1970), 61,067 (1996, minimum for the 20th century), 64,067 (2001), 77,189 (2011, maximum for the 20th and 21st centuries), and 71,637 (2017).
} 


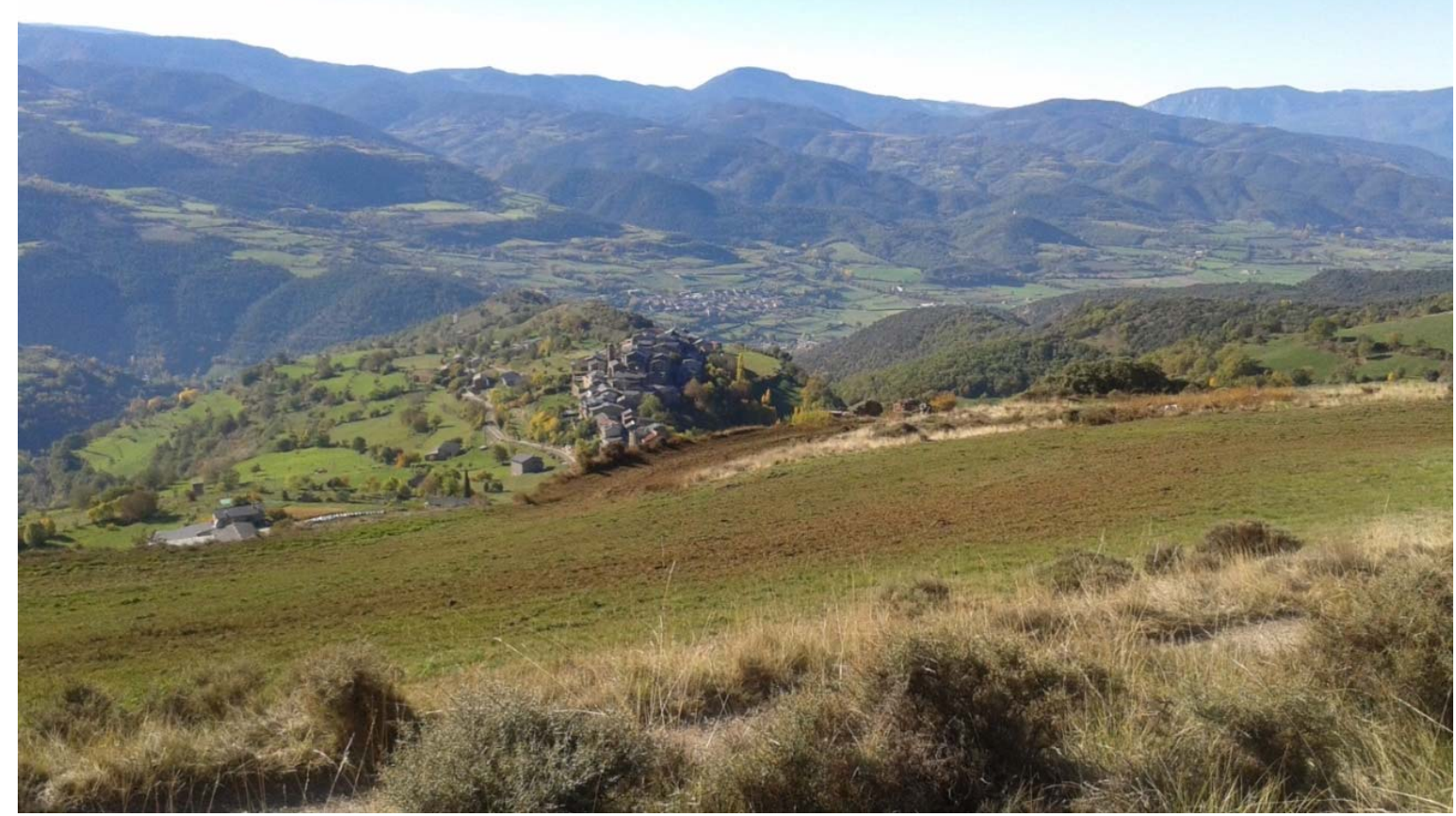

Fig 2. The HPA landscape: grassy fields, villages and forest in the Alt Urgell district. Source: A. F. Tulla

The aim of this study is to demonstrate that in peripheral rural regions, there is always some value-added activity or service that can enhance rural development by having a comparative advantage, and this very often implies a second-best option. The success of these experiences frequently depends on existing governance models for management of these activities and services (Little et al., 2012).

\section{A theoretical and conceptual framework}

In the European mountain areas, two opposing processes have coexisted since the mid-twentieth century: intensification of land use and abandonment of agricultural areas. This contradictory situation leads to conflicts between land use and landscape quality, with social, economic and territorial consequences (Antoine et al., 2011). Multifunctionality in rural areas has now appeared as a new development framework strategy (OCDE, 2001; Zasada, 2011).

There are positive and negative activities, trends, and consequences in the HPA region (PallarèsBarberà et al., 2005; Vera et al., 2011; Pallarès-Blanch et al., 2014; Barrachina et al., 2015; Pallarès-Blanch et al., 2015). On the plus side are: (a) organic agriculture, organic livestock production using natural pasture products (measured by biomass), product transformation industries, and organization of commercial distribution; (b) dairy products with high added value and of proven comparative advantage obtained by the transformation of cow's or goat's milk; (c) positive naturbanization with the immigration of professionals who engage in a range of activities and who have introduced new technologies in services and other innovations; (d) promotion of PNA and their contiguous territory; (e) local initiatives by town councils and civil society in general to promote green tourism, cross-country skiing, crafts and artisan activity, and tourist accommodation in rural hotels and farms, with the aim of creating new jobs; (f) employment opportunities arising from technological innovation and new forms of organizing the local economy, one highlight being the advantage of "spatial loyalty" and the territorial roots of these companies; ( $g$ ) justification of economic and social costs of services and infrastructure in mountain areas, which are usually more expensive within the context of "territorial justice" and in keeping with "social justice" goals; (h) economic and social benefits in border areas of mountain regions in the European Union; and (i) extensive livestock farming, which may choose to use sustainable resources, with a view to fostering biodiversity. Examples of positive and negative naturbanization can be seen in Figures 3 and 4. 


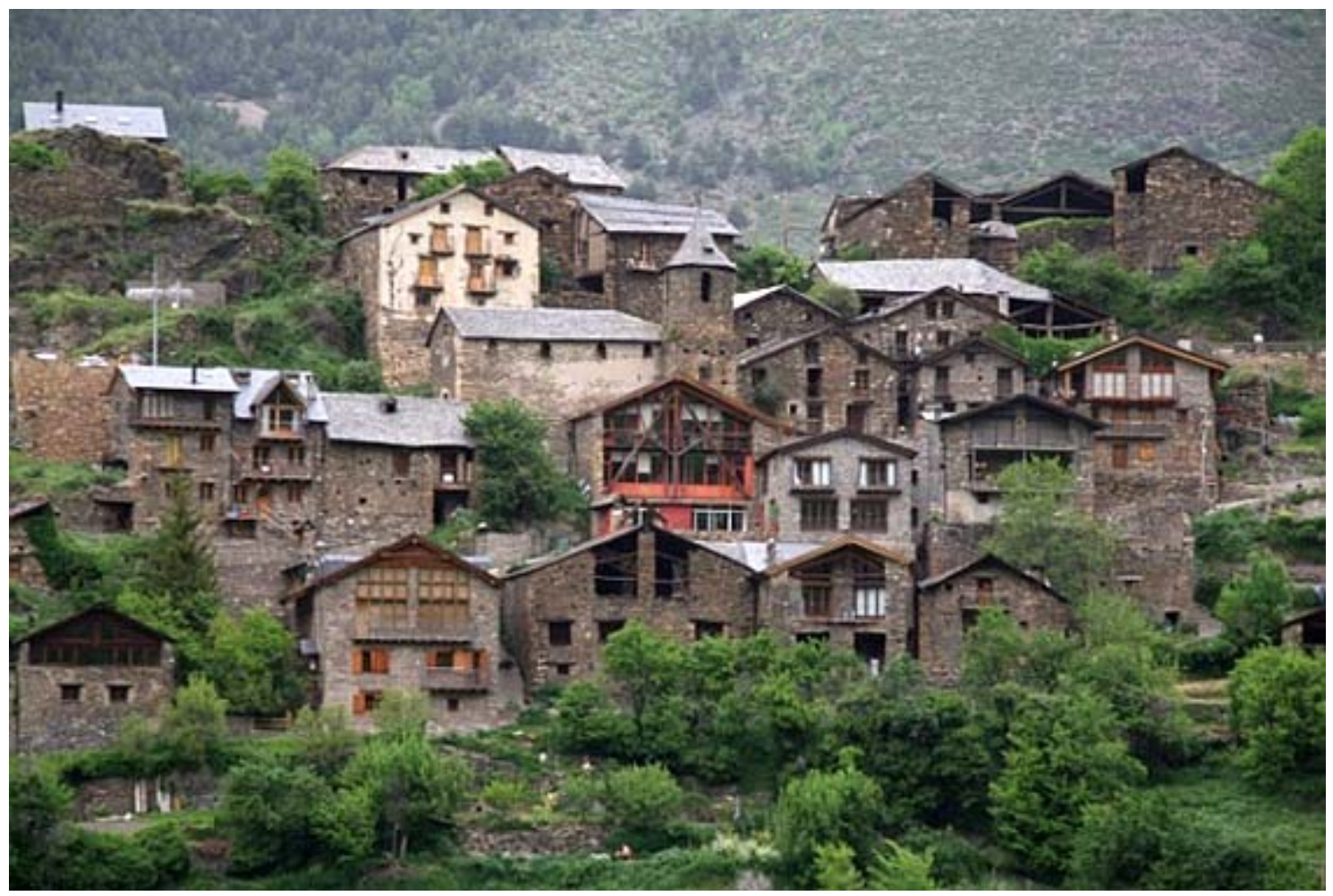

Fig 3. Restoration of an old village. Source: A. F. Tulla

Nevertheless, changes occurring in the Catalan Pyrenees also have negative consequences (Badia et al., 2010; Gosnell and Abrams, 2011; Sorensen, 2018). These include: (a) depopulation of small villages and abandonment of high mountain pastures and croplands, which reduces biodiversity as well as having adverse effects for ecological livestock farming because of updated infrastructure; (b) land use conflicts and fire hazards near PNA forests can result from intensive urbanization processes in areas of high landscape quality, although land-use planning and guidelines for forest-urban interface zones can prevent or mitigate impacts; (c) a parallel market has been created for land sales since, in general, prices depend on land use, which means that people wanting land to promote activities for urban uses can pay higher prices than those wanting the land for agriculture, a situation which requires planning and regulations to protect endeavors like agriculture or value-added agro-industry and to promote sustainable local development; (d) fertile soil is being taken for expanding towns and more second homes in rural areas, while the risk of fires and flooding is increasing as a result of mass tourism (alpine ski resorts, summer sports installations, little-used urbanizations for seasonal residents, and so on), all of which is detrimental to other, more sustainable activities, although problems could be avoided by giving priority to refurbishing older buildings in village centers, limiting urban expansion to land of low agricultural quality, and facilitating sustainable rural development; and (e) isolation, limited accessibility, and small populations are disadvantages of rural mountain areas so quality services must be ensured in order to alleviate these problems.

Valuation of PNA is particularly important in mountain areas, while their abundant natural capital offers resources that can lead to positive economies of scale (Copus and Hörnström, 2011). However, due to the characteristics of mountain areas, which can be summed up as extreme orography and climate conditions, these economies of scale are negative for competitive agrarian production aimed at large markets. Accordingly, among all the drivers of rural change, two are particularly basic in remote and mountain areas, these being the aforementioned abundance of natural capital (Pallarès-Blanch et al., 2015) and migration (Paniagua, 2002), which is the main factor of social change in the new rurality (Stockdale, 2006). It is in this framework where activities related to natural resources emerge and these are based on increasing production and transformation of quality products and/or handicrafts and, in many cases, certified organic production. They therefore contribute added value to primary production, creating a cycle of 
production and consumption that is not only more related with local values and resources, but also with a more sovereign way of life (Brown and Shucksmith, 2015). An important part of this entrepreneurship - also called eco-entrepreneurship - derives from an immigrant population (Baumgartner et al., 2013). The relationship of the new rural immigration with the development of economic activities that value natural and local resources has been demonstrated in several studies (Gosnell and Abrams, 2011, Herslund, 2012, Horlings and Marsden, 2014).

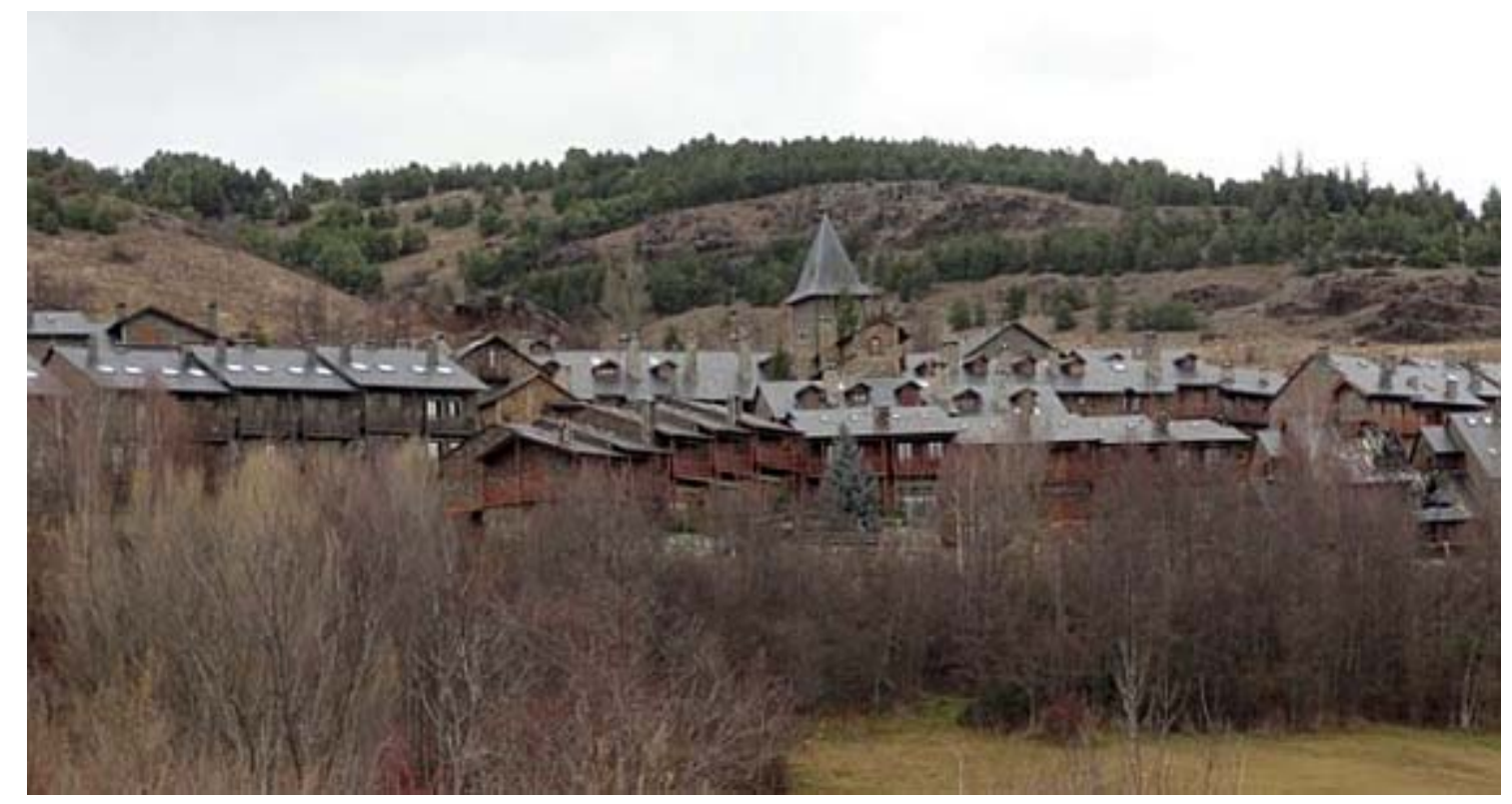

Fig 4. Building a new village without local roots. Source: A. F. Tulla

The principle of comparative advantage as defined by the classical school suggests that each territory will specialize in those goods and services it produces in better conditions instead of producing all the goods and services the territory needs. David Ricardo (1817) presents the theory of comparative costs between different regions where, when producing goods, costs are defined by natural conditions and historical development. This generates differential income derived from different qualities of the soil or available natural resources. Johann Heinrich von Thünen (1826) incorporates localization costs and transport costs into the previous analysis, adding local differential income. In the Heckscher-Ohlin model (Ohlin, 1933), emphasis is given to the characteristics of the factors of production in each region, for example, levels of technology and knowledge of the areas concerned, thus introducing the basis for studying added value. Hence, a territory will tend to export goods and services requiring intensive factors with which it is well endowed while it will try to import those goods and services that require intensive factors it does not have. It was Erling Olsen (1971) who stated that there is a relative advantage for each region, which can be measured by the opportunity cost if they specialize in production of goods and services with which they are best endowed. In other words, if these products or services do not exist, they should be imported.

Developed regions generate negative effects due to excessive growth and congestion. These diseconomies aggravate inequalities in development, as explained by Gunnar Myrdal (1957) with the center-periphery theory. Faced with these inequalities, peripheral regions can insert economic activities of comparative advantage, in relation with the large centers of production and distribution, into a network of innovative small and medium-sized enterprises (SMSE) reinforced by the spatial loyalty of the economic and social agents of the region (Navarro et al., 2018a). Each territorial area (Pallarès-Barberà et al., 2005; Peet and Hartwick, 1999) shows that development models increasingly move away from the simple growth of economic magnitudes and, especially in peripheral areas, give priority to small ventures based on value-added activities. 
The idea of "second-best option" $(\mathrm{SBO})^{4}$ (Lipsey and Lancaster, 1956; Lipsey, 2007) complements that of comparative advantage. Each territory can develop activities or services, even if other territories are better endowed, when this is the best specialization that can be opted for in that territory. The existence of an SBO for a territory means successfully promoting one or more economic activities that make it possible to achieve a comparative advantage and avoid opportunity costs.

Community agrarian policy (CAP) has attempted to reduce regional imbalances through the LEADER programs (Navarro et al., 2018b). However, there have been some perverse effects since local participation has been more formal than real. Moreover, local political and economic elites and lobbies have used some of these programs for their own benefit (Navarro et al., 2016). Nevertheless, the LEADER program has favored innovation, the creation of social networks, diversification of activities, and new forms of governance, which have enabled some regions to achieve a relative advantage (Esparcia, 2014), thus confirming the theory of comparative advantage. The contribution of these new activities in local development has therefore benefited neo-endogenous rural development and its relationship with social innovation (Neumeier, 2017). In the HPA, these programs have encouraged the establishment of women's entrepreneurship, which has become a key element in consolidating the comparative advantage of SBO activities (Viladomiu et al., 2010; Pallarès-Blanch et al., 2015).

In this region of study, examples of SBOs would include activities such as the transformation of dairy products, organic livestock meat, tourist activities that respect the natural environment, among them crafts, hiking or cross-country skiing, and even cultural events based on the historical, social and patrimonial wealth of the Pyrenees. In all these activities, there is significant added value implied by transformation or processing of products with the incorporation of knowledge, technology and innovation. Undoubtedly, these ventures could be carried out in other territories with greater success but, in this Pyrenean zone, they are the best options that can be developed with a comparative advantage. If it is said that some condition is missing in each case, thus preventing it from being optimal, it might be that the number of farms producing milk or meat is very small, that the level of innovation is not high enough in winter, or that there are not sufficient resources to maintain all the elements of cultural manifestations.

It has been possible to demonstrate comparative advantage as SBO for Alt Urgell and Cerdanya in the transformation of dairy products (Tulla, A.F. et al., 2009) and, for Ariège, with extensive ecological livestock farming (Eychenne, C., 2008). David Throsby (2001) suggests that the economic value of cultural heritage can give rise to a comparative advantage in certain territories. Glòria Bordons (2010) presents the literature of the Catalan Pyrenees as an activity that could generate added value in cultural heritage, with an enhanced comparative advantage when linked with other cultural events. Finally, sustainable tourism, instead of transforming the land, takes advantage of the natural and historical heritage and thus makes it possible to generate an activity of added value with local resources (Hall, C. M. and Lew, A. A., 1998).

\section{Methodological considerations}

The concept of "second-best option (SBO), formulated by Richard G. Lipsey and Kelvin Lancaster (1956), complements that of comparative advantage. They present it as a "Pareto optimum" equilibrium in which only one of the necessary conditions is missing. In our research, we assume that conditions for the development of profitable activities and services in a peripheral region are lacking. Rather than econometric analysis, we have opted for qualitative analysis (30 in-depth interviews and 9 focus groups - 3 in 3 districts - in the HPA region). The thirty in-depth interviews aim to learn about the experiences of the entrepreneurs. In contrast, the three meetings with the focus groups (experts, administration, and people responsible for activities) seek to elicit their opinion about which activities might be more successful and which would not in each district. In both cases, the questionnaires include some thirty questions ranging from characterization of

\footnotetext{
4 This proposes the "Theory of Second Best" (TSB) as a balance to the "Pareto optimum" in which only one of the necessary conditions is missing. In the present study, the idea that there is a lack of some condition for the development of profitable activities and services in a peripheral rural region is taken as a starting point.
} 
the entrepreneur or district activity, positive and negative impressions of the chosen activities, through to opinions on key issues.

This qualitative methodology offers better understanding of the activities of the area from a shorter or longer perspective and also allows assessment to be made of the most important activities in order to be able to apply the SBO method. Also, the comments important are, first by David M. Smith (1977), and then David M. Smith and Roger Lee (2004) on the contribution of Vilfredo Pareto to the economy and geography of welfare. They consider that this reveals criteria for locating activities efficiently or distributing resources equally and applying a certain ethics. However, they also recognize that it is a contribution limited by the typical restrictions of the theory, for example, application of the Pareto criterion in a no-growth economy, but they claim, too, that with some caution, it could be useful for certain applications, as would be the case with the present study.

Hence, it might be said of the SBO that "each territory can develop activities or services, even if there are other territories that are better equipped for them, when these constitute the best specialization for this territory". The existence of a territory's SBO means successfully promoting one or more economic activities that make it possible to achieve a comparative advantage. In the activities with comparative advantage cited above, there is an important added value that implies the transformation or processing of products through incorporation of knowledge, technology and innovation. Undoubtedly, these activities could be carried out with greater success in other territories but they are the best options to work with in this Pyrenean territory, a peripheral area with a comparative advantage. If some condition for optimal activity is missing, this might mean that there are not enough farms, or innovation levels can drop depending on the season, or more resources are needed for cultural projects.

In order to show how the SBO method works, four activities or land uses (rows) and three regions for implementing them (columns), have been chosen, as indicated in Figure 5 . The basic examples chosen are a simple way to provide this methodological demonstration.

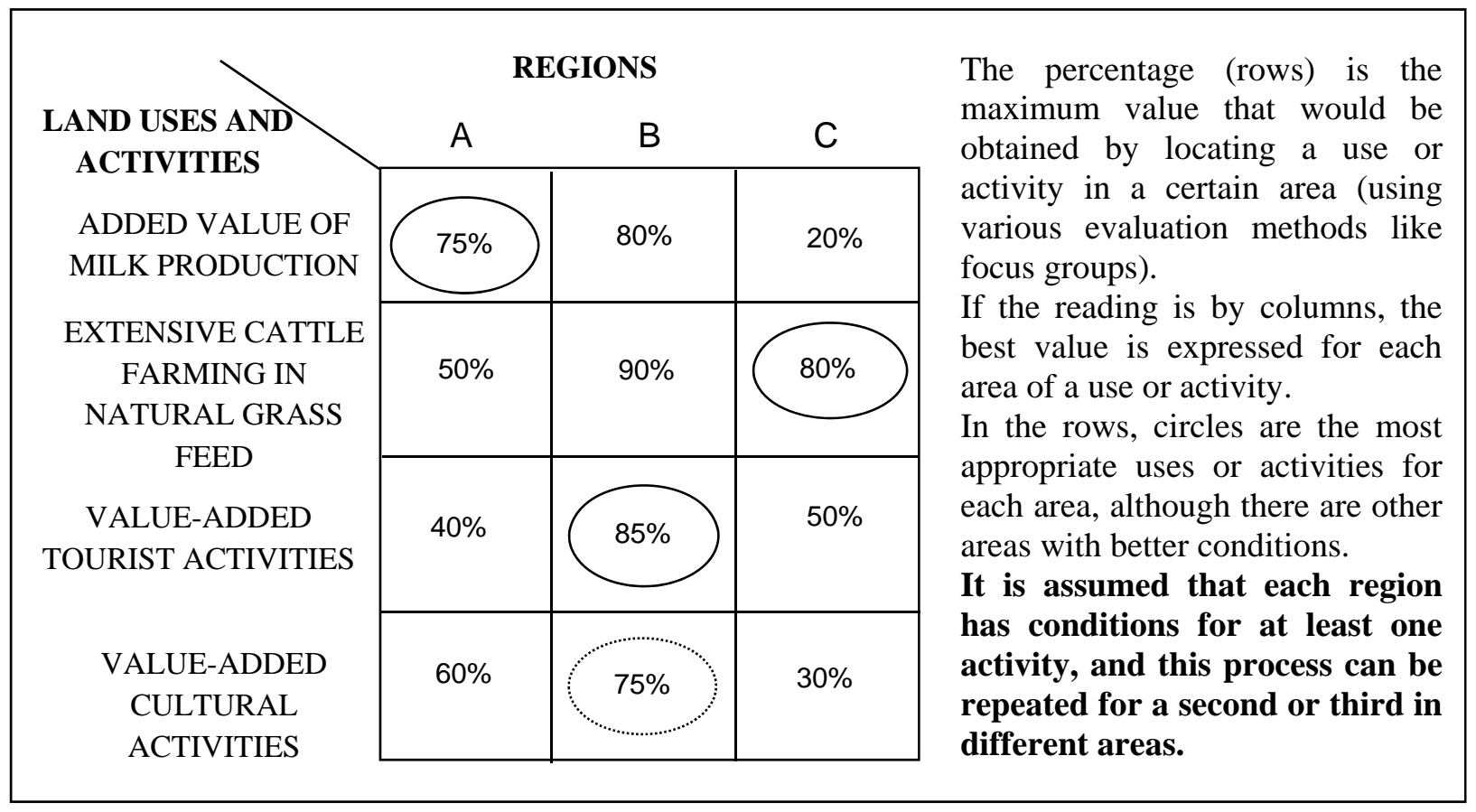

Fig 5. Comparative advantage and the "Second-Best Option" (SBO). Source: A. F. Tulla

If it is assumed that each region should have at least one of the activities, then that should be the one with which it is best-endowed (Tulla, A. F. et al., 2009). Various methods can be used to assess the positive and negative aspects of localization in each region, among them the opinion of a group of experts. In this research, we have used Focus Groups in three meetings (stakeholders from the administration and among local politicians; people involved in economic 
activities; and several specialists and technicians) for the three regions, namely A (Alt Urgell region), $\mathrm{B}$ (Cerdanya region) and $\mathrm{C}$ (Pallars region). Generally speaking, there is a questionnaire which has been prepared before each meeting. The main issues are related to the best activities or land use of each territory and the advantages or disadvantages of promoting them (Guinjoan, E., et al., 2016).

Region $B$ has the maximum values in the four uses or activities and would therefore concentrate them all, while areas $A$ and $C$ would have none. In the focus groups, there is general agreement that region $B$ conditions are the best for the selected activities. The comparative advantage when applying the SBO will entail looking for the best way of preparing each region for an activity, although there might be other better-equipped regions. Hence, Region A will host the transformation of dairy products into competitive value-added commodities (75\%) for which it offers the best conditions, Region $\mathrm{C}$, extensive cattle farming based on local natural grass feed $(80 \%)$, and Region B, the development of value-added tourist activities linked to the local landscape (85\%). Since each region already has an activity or land use, a second round could be started in Region B with the development of value-added cultural activities related to cultural heritage (75\%). The methodological process can continue with a selection of other activities and land uses. However, this mechanical presentation must be adapted to different nuances of each area where sometimes a combination of activities is presented rather than a single one.

\section{Results}

The value-added process to promote SBO activities and land uses is based on the multifunctionality of the Catalan Pyrenees Region. A multi-functional field means that rural activity can obtain multiple results, not only with the production of food and raw materials, but also with valueadded agro-food products, tourism, the environment, and social benefits.

At least five characteristics related to multi-functionality should be taken into account. (1) Agriculture can also contribute to the sustainability of the rural landscape, the protection of biodiversity, the creation of employment as well as diversifying agro-industrial activities and services, and thereby contributing to the viability of rural areas (Cuellar et al., 2013). (2) This new situation represents a "commodification of the countryside", where consumers who mostly live in cities are willing to pay more than the value of certain goods. A simple example is the comparative cost of agricultural land, where the price is based on the value of its production, whereas if this land is occupied by second homes or tourist activities, then the price depends on how much the buyer is willing to pay. So, the agrarian use of this land can be outside the market, which means that there is a double market for a parcel of land depending on the use that is to be given to it (Best, 1989). (3) The only solution for these rural territories is to implement planning policies for the activities and land uses that are needed, while avoiding the double market. (4) Often incorporating new technologies, some traditional rural activities like cycling, fishing, riding horses, boating, or hiking in the mountains, can become experiences to sell to tourists. (5) Women's entrepreneurship has improved some of the new activities around PNA (Burandt et al., 2017).

In the Catalan Pyrenees, at least four groups of activities which could be the best specialization for this territory can be studied: a) transformation of dairy products into competitive value-added commodities; b) promotion of extensive cattle farming based on local natural grass feed; c) development of value-added tourist activities linked to the local landscape; and d) the development of value-added cultural activities related with cultural heritage. These are activities with comparative advantage because of their capacity for generating added value, and also because they can be considered as a SBO for this territory. Then, each region specializes in products with comparative advantage in relation with other regions, making the most of natural and locational advantages, but also with better use of intensive or extensive factors and resources. 


\subsection{Comparative advantage and SBO for value-added dairy products.}

The main characteristics of this SBO activity may be summarized as follows.

Dairy farmers receive a higher price for milk than the average for France and Spain. The difference is returned as profit-sharing to the Cadí Cooperative (CCoop) members. Farmers pay lower prices for some inputs like "unifeed" (prepared for each farm and delivered "just in time") from the Pyrenees Cooperative (PCoop). The limited amount of available pasture land (Gross Livestock Unit/ha) is compensated for by better farm management, supervised by CCoop and PCoop. Cattle breeding is improved, there is a rotation of farm employees within the PCoop which reduces labor costs, while the use of "Unifeed" reduces feed cost per kg and lessens the need for more pastures when some of the crop production from farmers and other outside production is assigned as cattle feed for members. PCoop services improve quality of life for farmers (for example, through labor exchange to ensure continuity for holidays and sick leave, organizing family holiday groups, or obtaining institutional cheap credit for either production or consumption). The cooperative structure offers technological innovations (cattle breeding, artificial insemination, and work groups), leadership, and mutual assistance. Figures 7 and 8 show some images of final products and infrastructure of milk transformation.

\section{CADI COOPERATIVE (CC)}

- Price paid per $\mathrm{kg}$ of milk per year to CC members (1), including profit-sharing.

- Average prices, Spain (1985-2015) (2)

- Average prices, France (1986-2015) (3)

- $\mathrm{CC}$ in relation to Spanish average $(1965-2015)=19.3 \%$

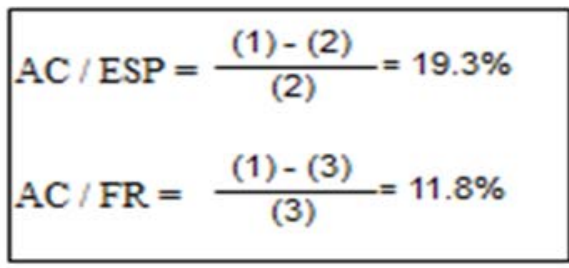

\section{PYRENEES COOPERATIVE (PC)}

- Annual cost to farmers for PC membership (1) (production factors, land rent, and labour)

- Average prices in Spain (1985-2015) (2)

- Average prices in France (1986-2015) (3)

$\cdot \mathrm{PC}$ in relation to Spanish average $(1985-2015)=-27.3 \%$

$$
\begin{aligned}
& \mathrm{AP} / \mathrm{ESP}=\frac{(1)-(2)}{(2)}=-27.3 \% \\
& \mathrm{AP} / \mathrm{FR}=\frac{(1)-(3)}{(3)}=8.2 \%
\end{aligned}
$$

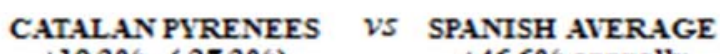

\section{CAIALAN PYRENEES VS FRENCHAVERAGE}

$+11.8 \%-(8.2 \%)=\quad+3.6 \%$ annually

Fig 6. Price differential for value-added dairy products. Source: A. F. Tulla, using data of Cadí and Pyrenees cooperatives, INE and INSE

Remuneration that is below market average for land and farm labor is offset by a "relationship with the land", an off-farm job, etc (Servolin, 1972). The individual or collective capacity for renewing "capital" (facilities, livestock, etc.) is essential, together with innovation, commercialization, and market competitiveness. Overall, farming is a good example of SBO: a competitive activity with high productivity in a structured confluence of all assumptions (Tulla, 1993). This very successful experience has been operative since 1915, although in 1960 there were 1,082 farmers in 6 cooperatives or dairies with a production of $16,280,900$ liters of milk, while in 2015 only 197 farmers produced 90,907,000 liters of milk, which was all delivered to the Cadi Cooperative. 


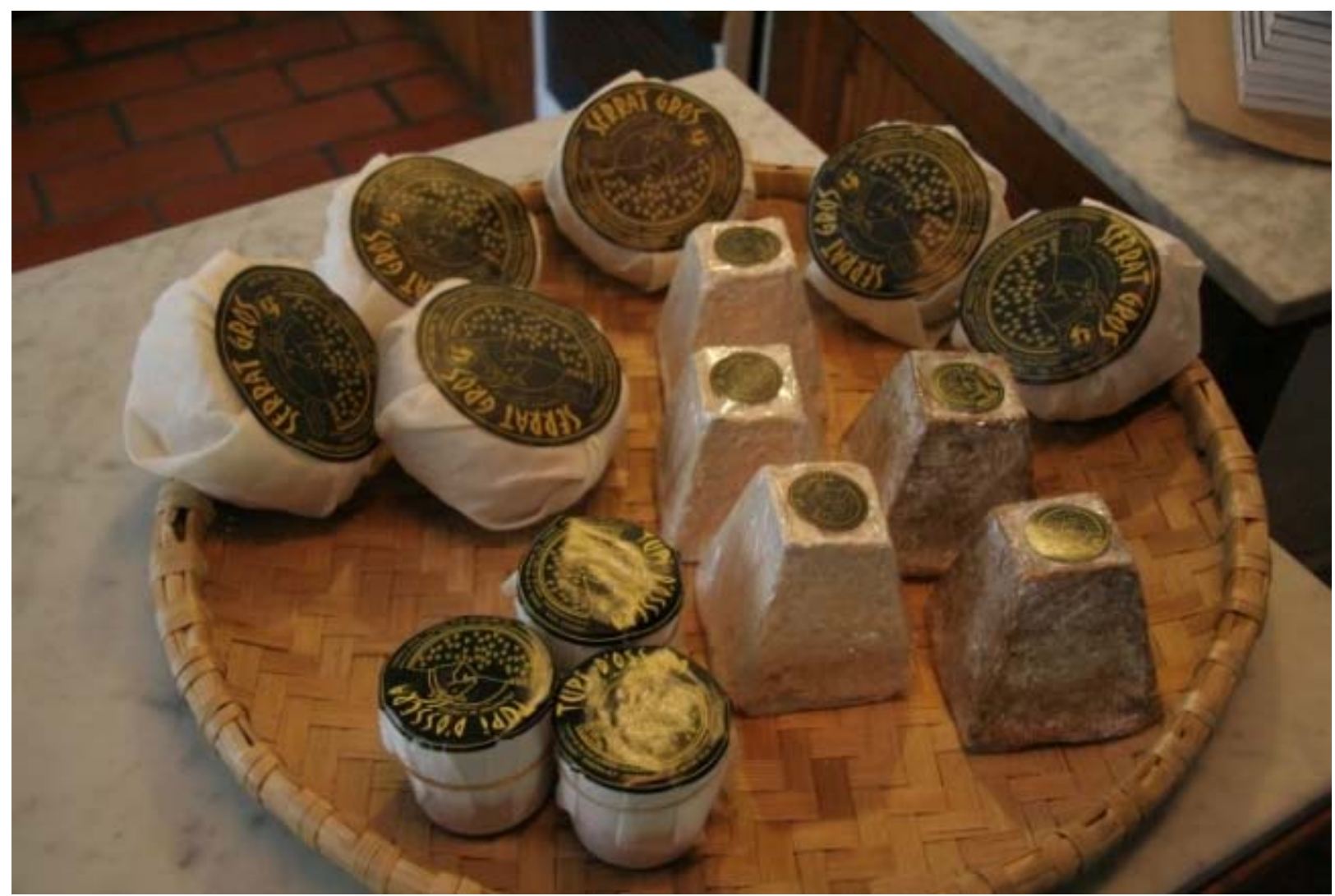

Fig 7. Artisanal goat cheese. Source: A. F. Tulla

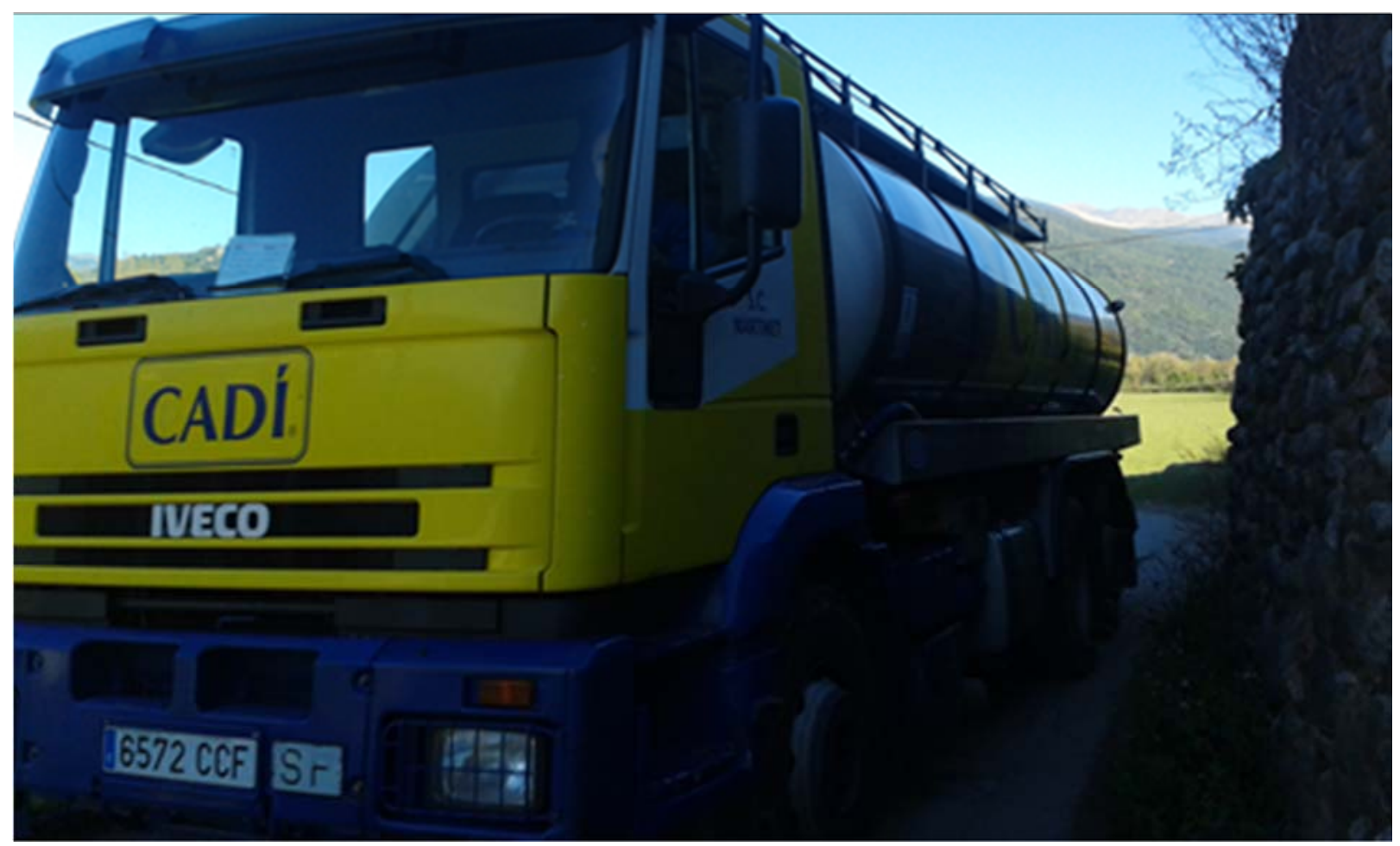

Fig 8. Cow milk collection for Cadi Cooperative. Source: A. F. Tulla

The milk collection of this cooperative is done on both sides of the French-Spanish border in the Cerdanya region. Nevertheless, there are several big farms that process their own yogurt and cheese for the local market in a more organic and proximity-oriented trade approach. Production has risen from an average contribution of 15,055 liters per farmer to 461,457 liters (Pallarès- 
Blanch et al., 2013). However, the important thing is that there has been an increase from 47 to more than 100 people working in the production, processing, and distribution of processed dairy products (cheese, yogurt, butter) because of the added-value process and the SBO. Some of the products have the status of "denomination of origin" and they can be sold at higher prices because customers recognize their quality, and $50 \%$ of the production is sold to other countries (Tulla et al., 2009; Vera et al., 2011; Marmol et al., 2016).

\subsection{Organic grass-fed livestock production based on locally grown feed crops.}

The second case analyzed here is that of organic grass-fed livestock production based on locally grown feed crops. The study has been carried out in the Vall Fosca of the Pallars region in the HPA (Barrachina, M. and Tulla, A. F., 2010; Barrachina et al., 2012; Monllor, 2013; Barrachina et al., 2015). This activity assumes that: 1 ) extensive livestock farming diversifies the mountain economy with pluriactivity that encourages local development and preserves the rural agropastoral landscape; 2) extensive farming supports biodiversity and environmental quality with livestock migration and because it maintains grass fields with the aim of breeding cattle through natural grass production, as well as engaging in forest management (see Figures 9 and 10); 3) food and medication controls allow extensive organic production but it is very difficult to buy organic feed in Catalonia because, in 2017, there were only two producers and they were located far apart, although there is a new initiative nearby in the Aragon region which has adapted production to Catalan regulations; 4) this scarcity of providers is a weak point for organic cattle farming; 5) if there is knowledge of soil quality and the vitamin/mineral needs of the animals, it will then be possible to plan grass production as well as externally supplied needs (medication, minerals, and so on); 6) calculation of herbaceous biomass production needed to feed the animals on site (remote sensing images, dry production in the laboratory, and microclimates were used to carry out measuring and evaluation in this research) can guarantee high levels of natural local feed; 7 ) in the case of complementary feeding, with minimum organic feed and transhumance it will be necessary to buy more organic feed from specialist providers like the aforementioned one in the Aragon region.

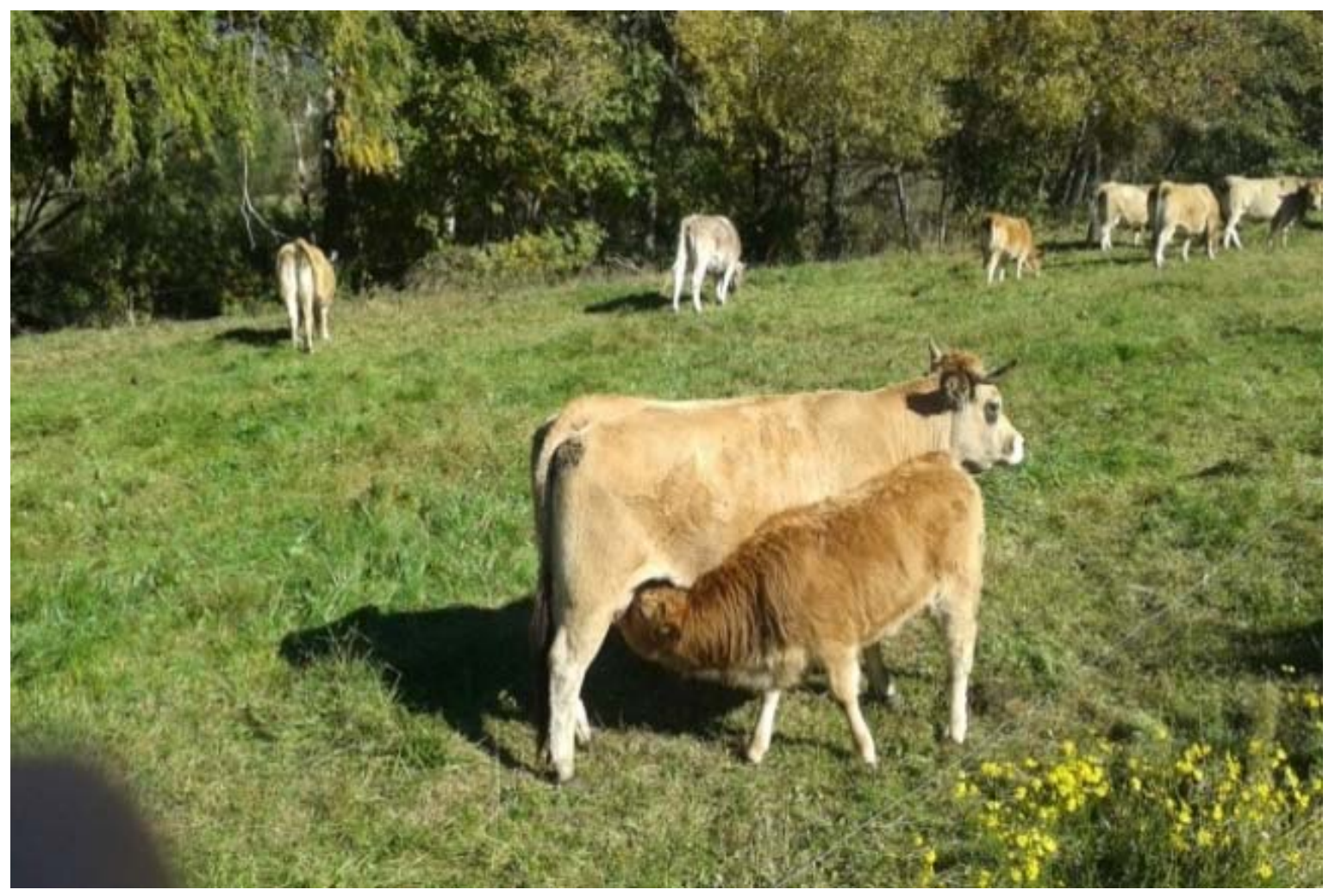

Fig 9. Organically fed cows. Source: A. F. Tulla 
An established clientele of butchers and consumers regularly supplied with products of reliable quality can guarantee that most of the organic beef production will be sold. A loyal clientele is necessary to assure the viability of the project. Simplifying the bureaucracy entailed in the process is one of the major difficulties of producing organic meat in Catalonia and Spain. District agricultural assessment agencies are crucial if the project is to succeed. It is not easy to get access to a butcher's shop or slaughterhouse to cut and prepare the beef and it will therefore be necessary to obtain these services from the local administration, farmers' associations, or trade union organizations. It is also essential to work in partnership with local producers in order to share effort and expense in obtaining ecological inputs, distribution channels, and quality designations.

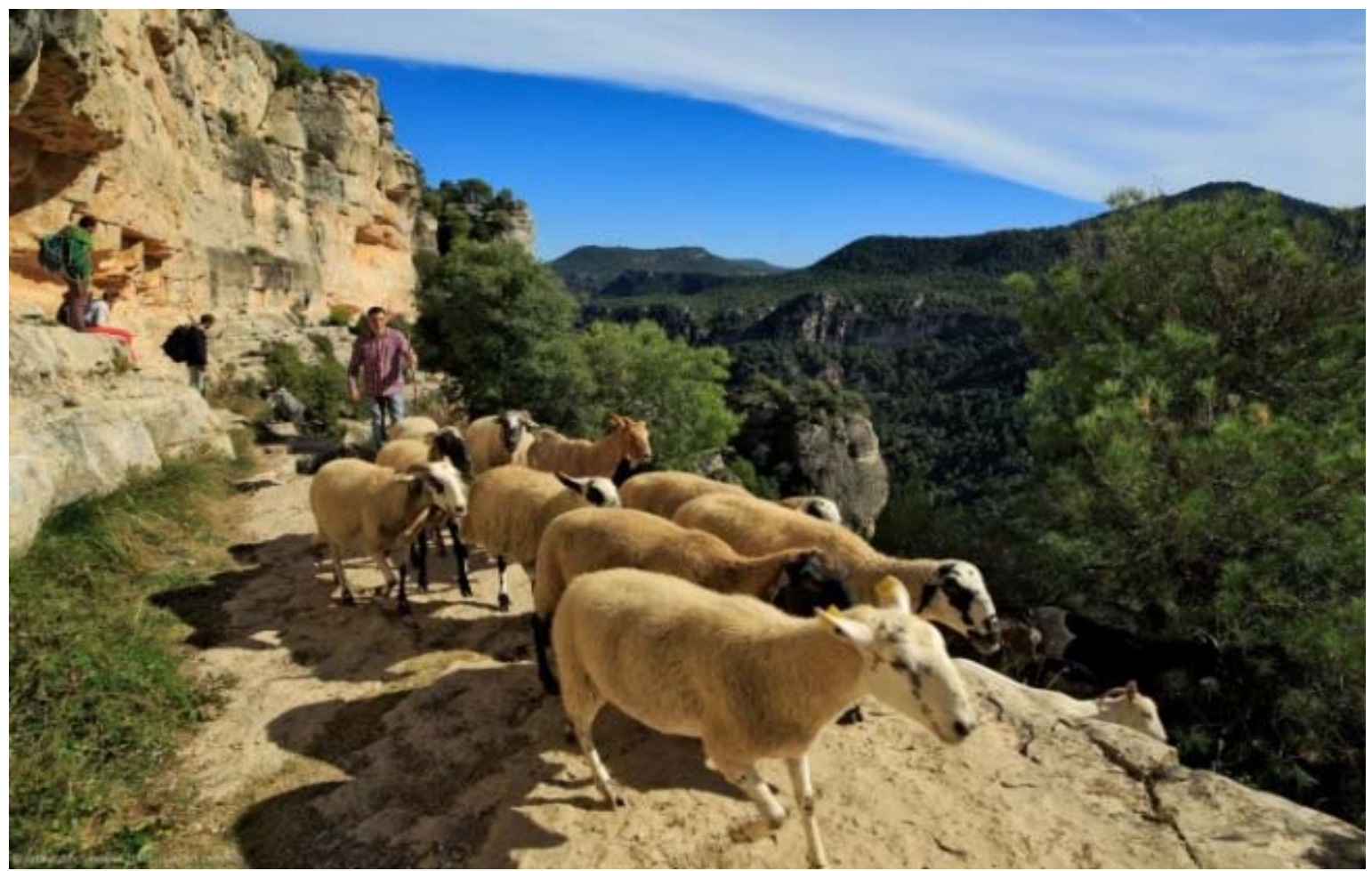

Fig 10. Flock of sheep. Source: R. López Monné

Organic grass-fed livestock production can earn "denomination of origin" status if feed and pharmaceuticals are "ecological" or organic. The specific regulations for organic production in Catalonia are very strict and represent further difficulties in the process of organic meat production. Access to "proximity circuits" orientated to local customers, butchers and restaurants is not sufficient because the main consumers live in urban coastal settlements of Barcelona, Costa Brava and Tarragona (200-300 km away). It is then necessary to establish some form of organization, in the form of partnership in the district or by providing refrigerated transport. In other words, this endeavor is not only a matter of organic cattle production but it also entails the creation of a local partnership organization and a distribution network for the products.

Moreover, it is necessary to recover old experiences of heritage breeds and to work in initiatives like the "Herders' School" (Escola de Pastors). ${ }^{5}$ This experience has been in existence for more than ten years and aims to recruit people, mainly from urban areas, who are interested in farming in the HPA. Each year, there is a prior selection of some 15-20 people who will acquire basic knowledge of farming and grazing. They also work for one or two years on a selected farm where the owner agrees to teach them practical skills. Every year, thanks to land-management organizations like "Custodia Agrària" (Agricultural Stewardship), it is possible to settle 8-10 new

\footnotetext{
${ }^{5}$ http://www.escoladepastorsdecatalunya.cat/
} 
farmers in the Ariège department on the French side of the border as well, depending not only on their ability but also the number of vacant farms available. ${ }^{6}$

This activity is complemented with sustainable tourism in the area as well as second homes, small hotels, campsites and the services they generate. It is important to note that in this valley, at an altitude between 800 and 2400 meters, with an area of $180 \mathrm{~km}^{2}$ and 1,079 inhabitants (in 2008) ${ }^{7}$, depopulation has slowed down and a diversified economy has been generated. Foreign immigrants (from Eastern Europe, Latin America and sub-Saharan Africa), who arrived between 1995 and 2015, currently represent $18 \%$ of the population. The number of livestock farms has dropped from 51 in the 1999 census to 38 in 2015, with areas of between 20 and 50 hectares, and an average of a hundred cows and calves. ${ }^{8}$ There are also five flocks of sheep and goats. It is undeniable that recognition by the Consell Català de la Producció Agrària Ecològica (CCPAE - Catalan Council for Ecological Agrarian Production) ${ }^{9}$ has given value to beef and sheep production, which means that value-added production complemented by sustainable and family tourism, has also been achieved.

Finally, the fact that this valley includes part of the territory of the National Park of Aigüestortes and Sant Maurici, thus promoting positive naturbanization (Barrachina, M. and Tulla, A. F., 2010; Pallarès-Blanch, M. et al., 2014), must also be taken into account. Some of the unknowns about the future of mountain agriculture are how to solve the generational changeover, finding skilled labor, for example, shepherds and making land available for young entrepreneurs. In this sense, the Projecte Gripia Territori Ramader ${ }^{10}$ is very important, since the idea is that farmers can train young people on their own farms or they can be trained externally in order to take over the farm when the time comes. This initiative is complemented by the Shepherds School (Escola de Pastors) and the Land Bank (Banc de Terres).

Although the valley's economy was thriving in the first half of the twentieth century thanks to the hydroelectric industry, it has focused on traditional agricultural and tourist activities since 1960. However, in 1998, the municipal authorities, together with a real-estate construction company, promoted the "Vallfosca Mountain Resort". A ski area covering 3,400 hectares was planned to link up with the current Ski Resort of Boí-Taüll, and included the construction of 7,400 residential spaces (65\% in hotels and 35\% in apartments) for an estimated 3,500 skiers. This project was rejected by civil society, which preferred activities that were more ecological and respectful of the landscape. The economic crisis of 2008 settled the debate in favor of the environmentally-friendly position and this was complemented by commercially oriented organic meat production and a shift to sustainable and family tourism (Barrachina, M., 2011).

\subsection{Development of value-added tourist activities linked to local landscape}

Tourist activities are very diverse but, in the mountain areas, these can be summed up in two types. Firstly, there are those that consume space and require large investments, for example, alpine ski resorts and the urbanization process that accompanies them. Secondly, there are activities, which - like hiking - take advantage of the rural environment and the natural landscape and have less impact on land uses. Basically, the matter boils down to mass tourism versus alternative tourism. The latter includes naturbanization, the attraction of the natural landscape, rural tourism, adventure tourism, Nordic skiing, fishing, hunting, hiking and handicrafts, among other possibilities. In any case, two key facts should be taken into account: commodification of the natural space and the countryside in general, and the fact that tourism in peripheral rural areas should always be considered as part of a whole context. Tourist activities are important since they can promote added value with the creation of employment and the multiplier effect on other activities (Wight, 1998). Rural tourism allows the development of a range of activities that complement the income of each family, in particular, and of an entire territory in general (Milian,

\footnotetext{
${ }^{6}$ https://custodiagraria.wordpress.com/

7 IDESCAT (2016) Estadística bàsica territorial. Barcelona, Institutut d'Estadística de Catalunya.

8 IDESCAT (2012) Cens Ramader (1982-2009). Barcelona, Institutut d'Estadística de Catalunya.

${ }^{9}$ Catalan Council of Organic Agrarian Production

$10 \mathrm{https}$ ///projectegripia.wordpress.com/about/
} 
2011; Pallarès-Blanch et al., 2014). This model has been described in the work of Margarita Capdepón (2015) on natural parks in the Alicante region, and also in the proposals of Dallen J. Timothy (2011), connecting cultural heritage and tourism.

Urban development in mountain areas due to increased mass tourism currently constitutes a trend in Europe. In the Catalan Pyrenees, this phenomenon has occurred for two reasons: an increase in the number of alpine ski resorts, and the construction of second homes, apartments and hotels which consume space, which is often also that representing the best quality for agricultural activities (Barrachina, 2009). When planning is absent, the agrarian land market favors activities that bring in the highest price per square meter. Projects of building second residences or ski resorts are based on the income capacity of city dwellers with better salaries or income from urban activities.

By contrast, the price that farmers can pay for the land depends on the sale of agricultural products, and their income is lower than that of city dwellers. Furthermore, the most fertile land at the bottom of the valleys is disappearing and it is increasingly difficult for farmers to keep going. In this sense, it is necessary to plan land uses in mountain regions in order to preserve a minimum amount of land for optimal production in agricultural activity (Tulla et al., 2009). Besides, if tourism is to be sustainable, resources must be used in such a way that they can be reused afterwards. Urbanization, for use by a limited number of people and for a specific purpose, is clearly unsustainable because single-use land represents "bread for today and hunger for tomorrow". More and more attempts are being made to preserve designated spaces for certain activities like agriculture, while most spaces are assigned for alternative tourism in its various forms (Vera et al., 2011).

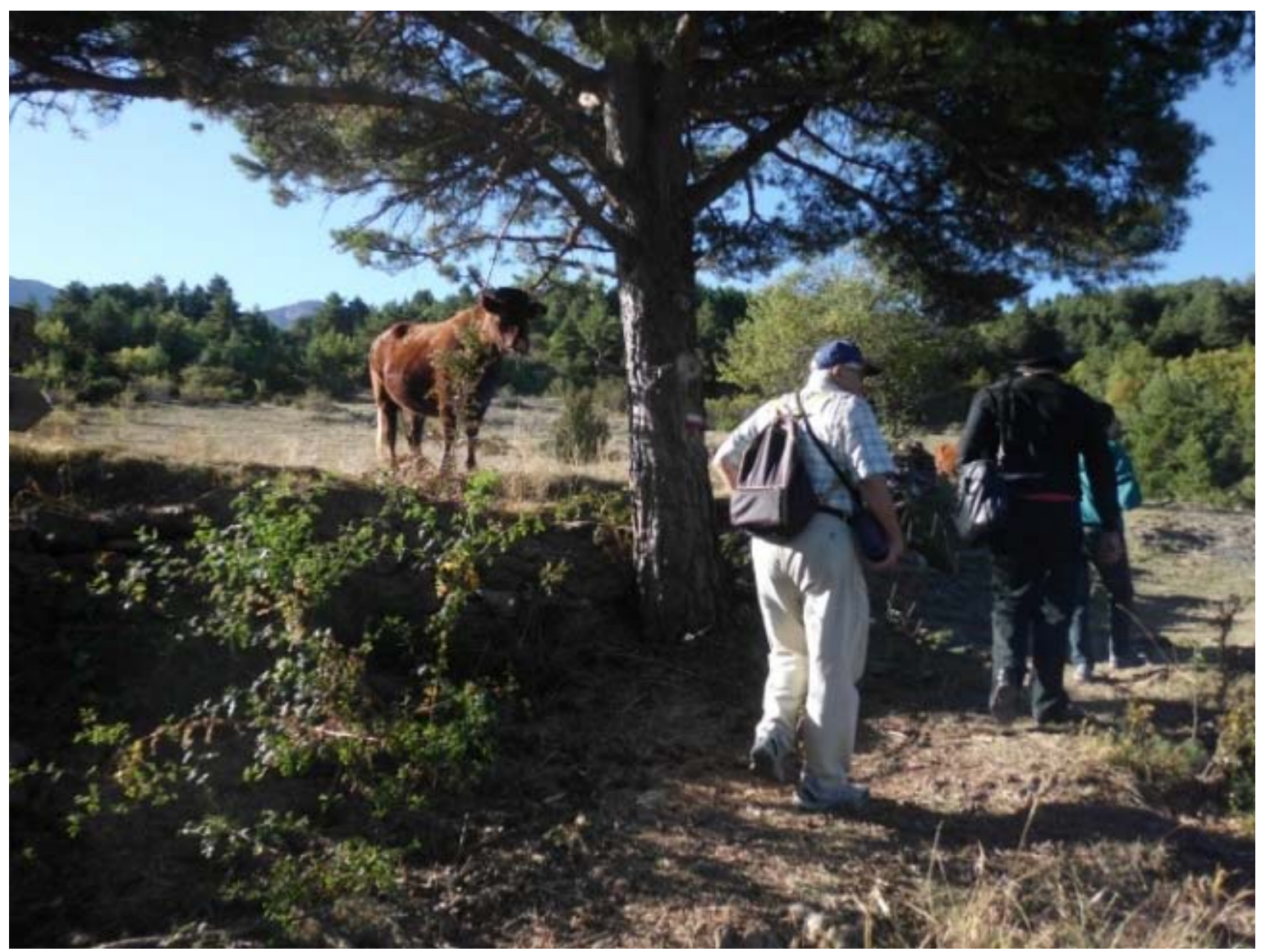

Fig 11. Hiking. Source: A. F. Tulla

In the Catalan Pyrenees, sustainable tourism has developed around protected natural areas where visitors can go hiking and cycling (Figures 11 and 12). However, there is a clear contradiction between conservation of these spaces and the need to foster agricultural activities that must use their resources (pasture for livestock, forest management, etc.) or promotion of 
environmentally friendly tourist activities (Roberts and Simpson, 2003). Ecotourism, which prioritizes friendly contact with host communities and the environment, is becoming progressively more important (Wearing et al., 2012) and the so-called "slow ecotourism" needs to embrace principles of social justice and sustainability to achieve this relationship. Rural guesthouses and small hotels are increasingly used to accommodate people who want to go hiking or Nordic skiing, or to enjoy family tourism. Local tourism associations, created for the whole territory, facilitate access to various leisure and tourist activities. A large number of the entrepreneurs are people from outside the region and many are women (Pallarès-Blanch et al., 2015).

This network of connections extends to the public-sector services, on the one hand, and to private-sector commercial and financial activities, on the other. The result is the creation of a tourist cluster which takes the demands of the local population into account as well as offering a wide range of tourist activities. This has given rise to a considerable amount of employment in these mountain areas, thanks to the added value of many of these activities as well as the ways in which they combine (Pallarès-Blanch, 2012). The existence of a "geographically based appellation system" (Goulart et al., 2015) helps to increase added value either in the form of products (cheese brands, organic beef, and so on) or in services, for example, some types of tourism.

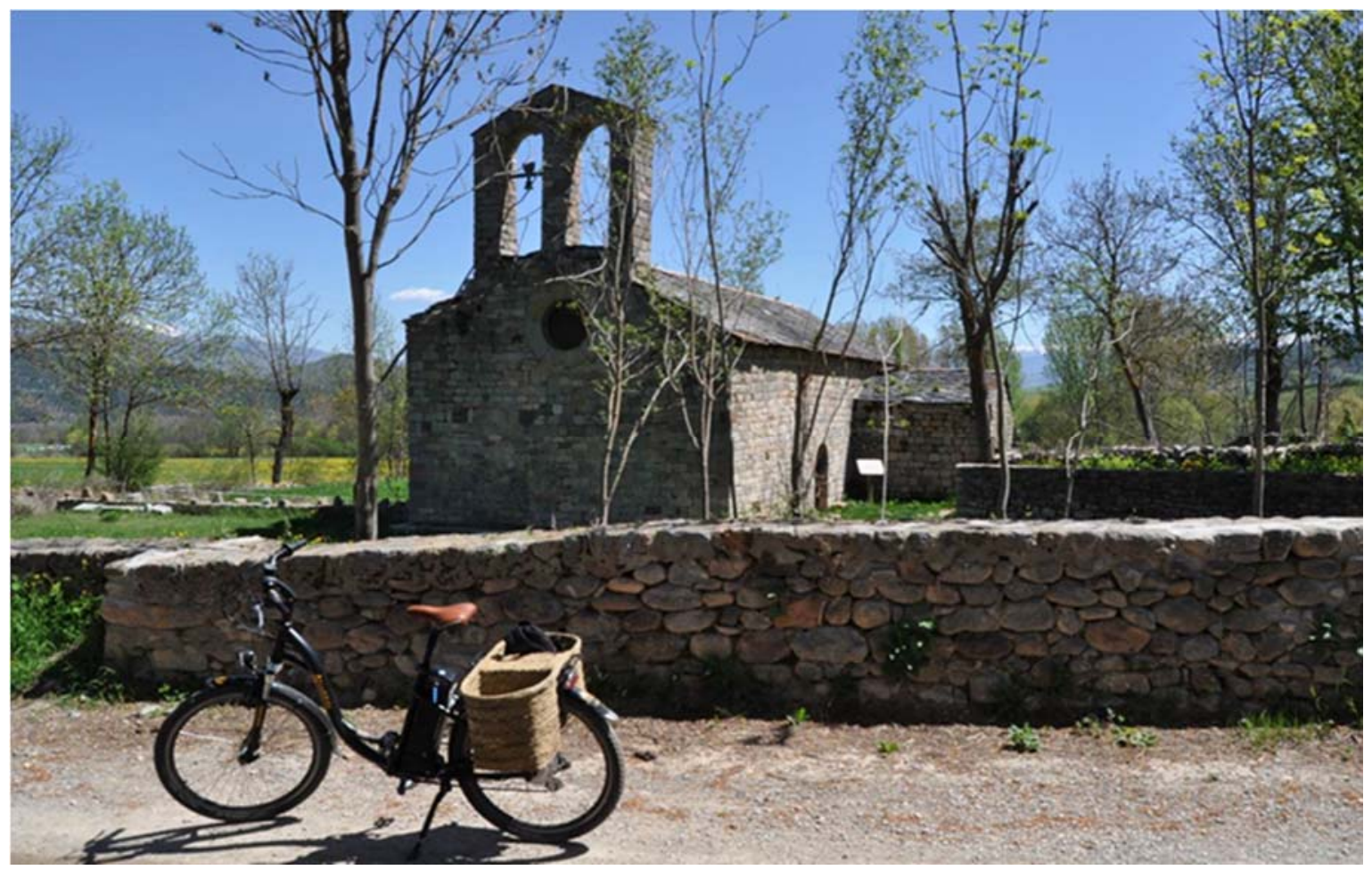

Fig 12. Cycling. Source: A. F. Tulla

There are several actions that can be regarded as local development with added value. This would be the case of a growing interest in riding the rapids of whitewater Rivers in canoes or rubber boats. There are two outstanding places in the Catalan Pyrenees where this can be done, Llavorsí in the Pallars district, and the Seu d'Urgell in the Alt Urgell district. The chief difference between them is that the former case is a river with many rapids and the latter consists of a very sophisticated installation that was built for the 1992 Olympic Games. Both of these areas are highly attractive for sportspeople who want to train and for the holding of international competitions. In addition, school children and tourists enjoy this activity and hence, many foreign monitors are attracted to these places together with young people in the region who are showing a growing interest in finding work in this sector. The multiplier effect of this activity has been significant: accommodation, commerce, and especially small workshops for the repair and sale of river sports equipment. In the Seu d'Urgell, the Cooperativa Cadí sponsors a project offering initiation into this sport, while also connecting the sale of its products with tourist promotion of 
the district. The Pallars region has seen a significant increase in population in relation to this activity, as well as a return of people who left the region, (Solé et al., 2012).

The combination of whitewater canoeing, with canyoneering (hiking down canyons using rock climbing, rappelling and other techniques), climbing, and paragliding centers, constitute an "adventure tourism cluster" (Figures 13 and 14). With greater numbers of visitors and monitors with technical knowledge, there is a rising demand for accommodation and specialized shops. Another combination and cluster of tourist activities is hiking, mountain biking and Nordic skiing, using rural tourism houses or community accommodation, and with the participation of specialized guides. These activities have also favored the creation of shops selling mountain equipment and travel bookstores. Electric bicycles are also becoming popular, thus giving rise to shops and facilities suitable for them.

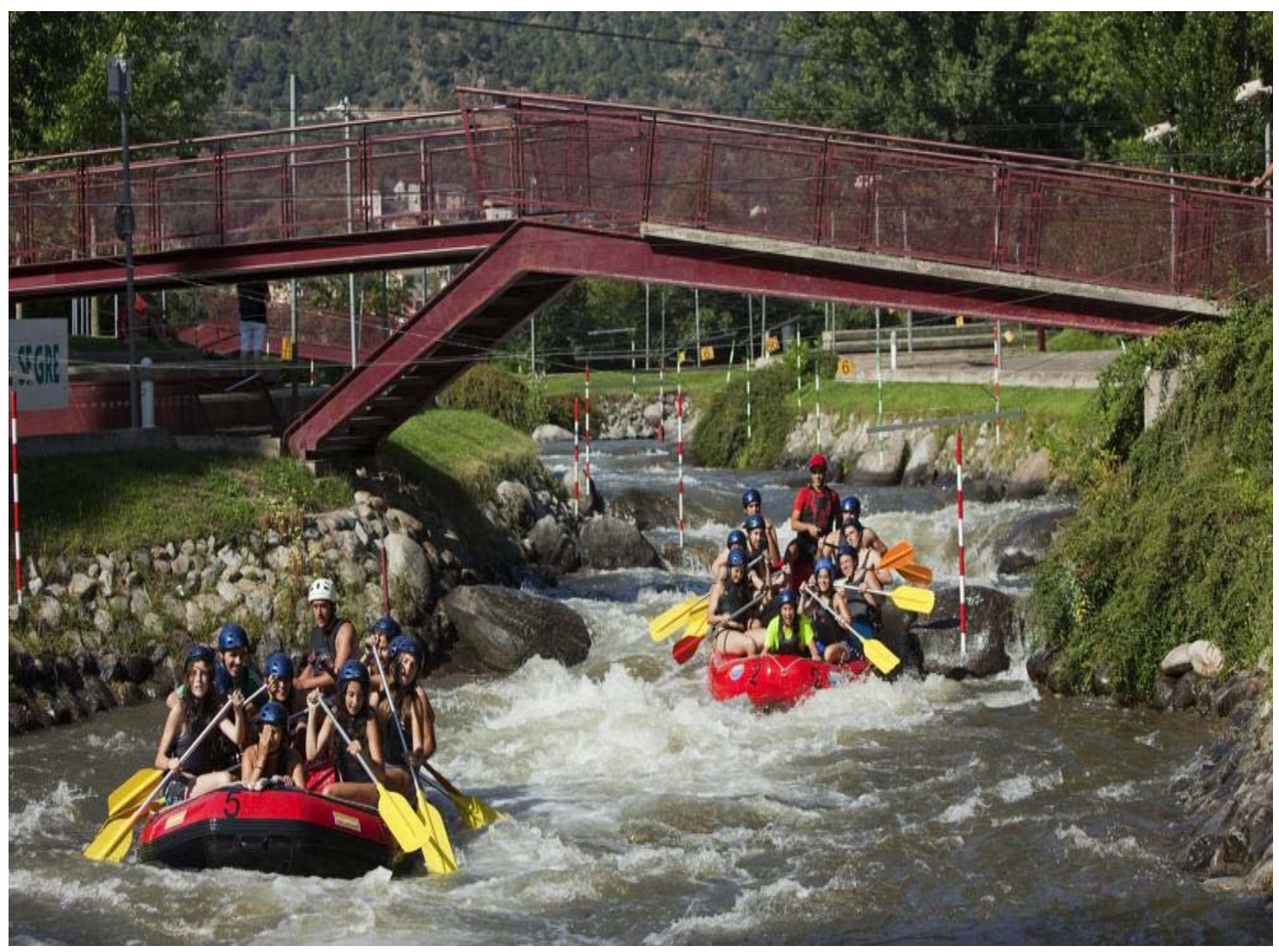

Fig 13. Whitewater rafting in inflatable boats. Source: Parc del Segre

An increasingly common separate activity is long-distance mountain races. Among the most popular is the Cadí-Moixeró Natural Park loop route (39 km in 2 days) in the districts of Alt Urgell, Cerdanya and Berguedà, and the "Carros de Fuego" (Chariots of Fire, $76 \mathrm{~km}$ in 5 days) in the Aigüestortes National Park and Sant Maurici, in the districts of Pallars, Ribagorça and Val d'Aran. In both races, which help to promote protected natural areas, runners must manage great differences in altitude, and the stages end in mountain shelters. These sports events have become a great tourist attraction which is complemented by a demand for accommodation and catering, and also bringing in a higher income for commercial establishments.

Family tourism combining a stay in mountain areas with visits to the artisan centers producing food products, textiles, ceramics, sculpture or woodwork, is increasingly popular. Moreover, there are growing numbers of specialized museums in each district, with collections related with traditions like sheep's wool products, wine production, ice wells, and woodworking, among others. The result is a better integrated tourism in the territory, as well as creation of employment (museum staff, tour guides, employees of commerce or hotels, etc.) which has stopped the process of depopulation or even increased the population. 


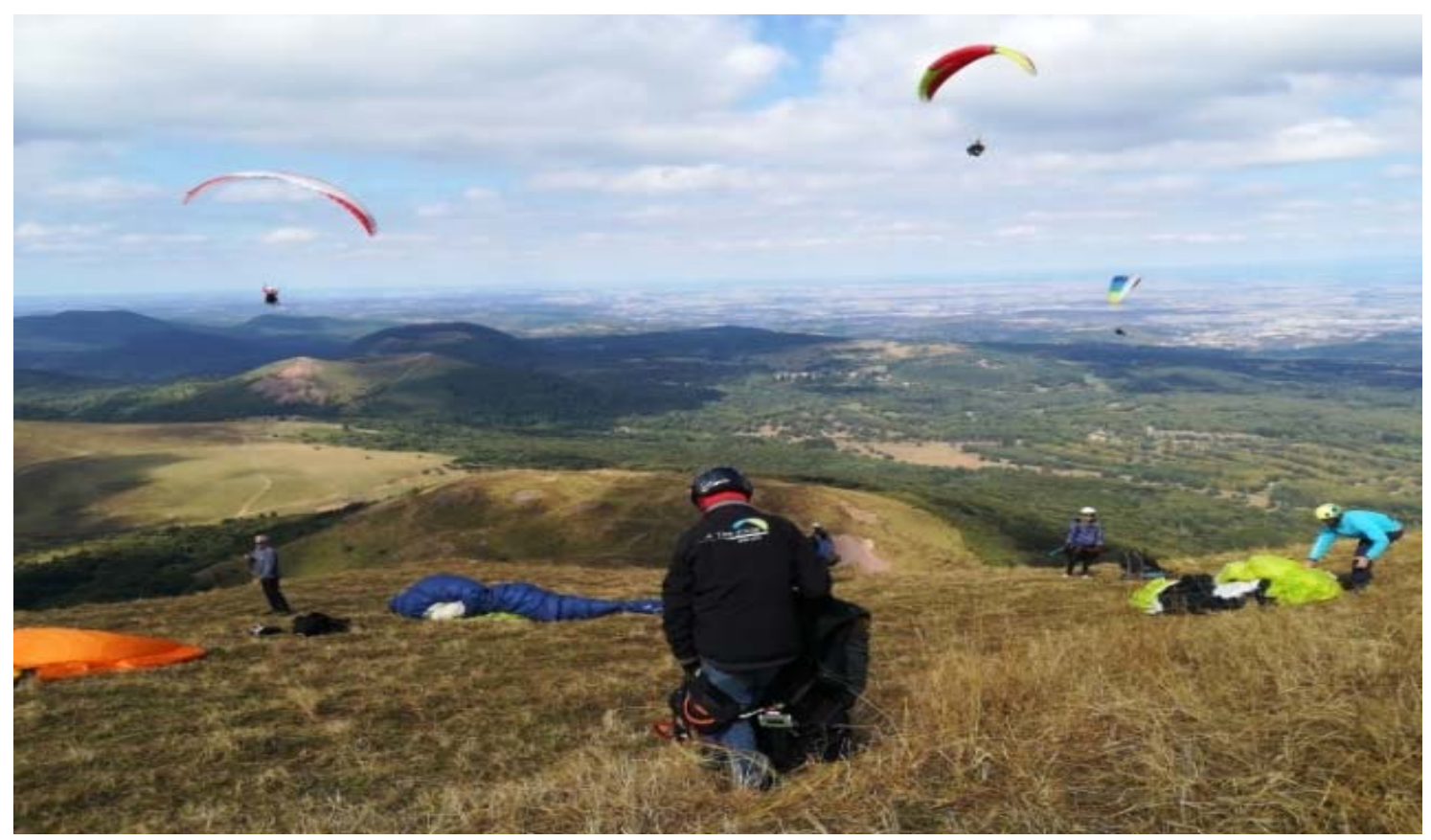

Fig 14. Paragliding. Source: A. F. Tulla

In the period 1975-2000, many second residences were built but in the twenty-first century, collective establishments have become more frequent because they adapt better to the seasonality of tourism. Overall, more than a third of the tourists coming to the Catalan Pyrenees, especially protected natural areas, or for adventure sports, are foreign. It has been shown that, in recent years, tourist occupation tends to double the local population (Mendizabal et al., 1993; Pallarès-Blanch et al., 2014:146), although the greatest numbers are concentrated in summer and winter, and during weekends. The fact that the area has borders with France and Andorra favors the high number of visitors (Pallarès-Blanch et al., 2013).

\subsection{Development of value-added cultural activities related to cultural heritage}

Finally, the fourth case, development of value-added cultural activities related with cultural heritage and social life (Prados, et al., 2012; Pallarès-Blanch et al., 2015; Tulla et al., 2017), should be understood as a cluster of cultural activities that multiply their value by consisting of a global offer of mountain villages rather than the sum of isolated activities. It is very important that the strategy should be based on all elements of the cultural heritage since they can fail in isolation, as it has happened with the "interpretation centres" in some Spanish regions (Arcila y López, 2015). The main types of activities aiming to recover the cultural and social fabric of the Catalan Pyrenees are listed below:

(1) Annual village festivals ("Festa Major"). In each town or village, there are one or two festivals a year that attract people from other towns in the district as well as tourists. In mountain areas, there is coordination among the populations so that they can be presented as a joint activity.

(2) Livestock, agricultural, and handicrafts fairs. There is a tradition of holding livestock fairs in the spring and fall, before livestock is moved up to high pastures and when they return to the villages. These are activities that attract many tourists.

(3) Cultural festivals ("Falles", "Raiers", "La Patum", "caps grossos i gegants" - "big heads" and giants - et cetera). More and more thematic festivals are being held in each place, many of them now recovered after lapsing because of rural depopulation. Some have been named on the UNESCO Representative List of the Intangible Heritage of Humanity (see Figure 15).

(4) Libraries, bookstores, civic centers, and gatherings of writers and painters. There is a great wealth of publishers and book stores in Pyrenees market towns, and even several annual gatherings of writers from this mountain area. In addition, in conjunction with the agrarian crisis, the existence of artists and artisans in small villages has increased significantly. 


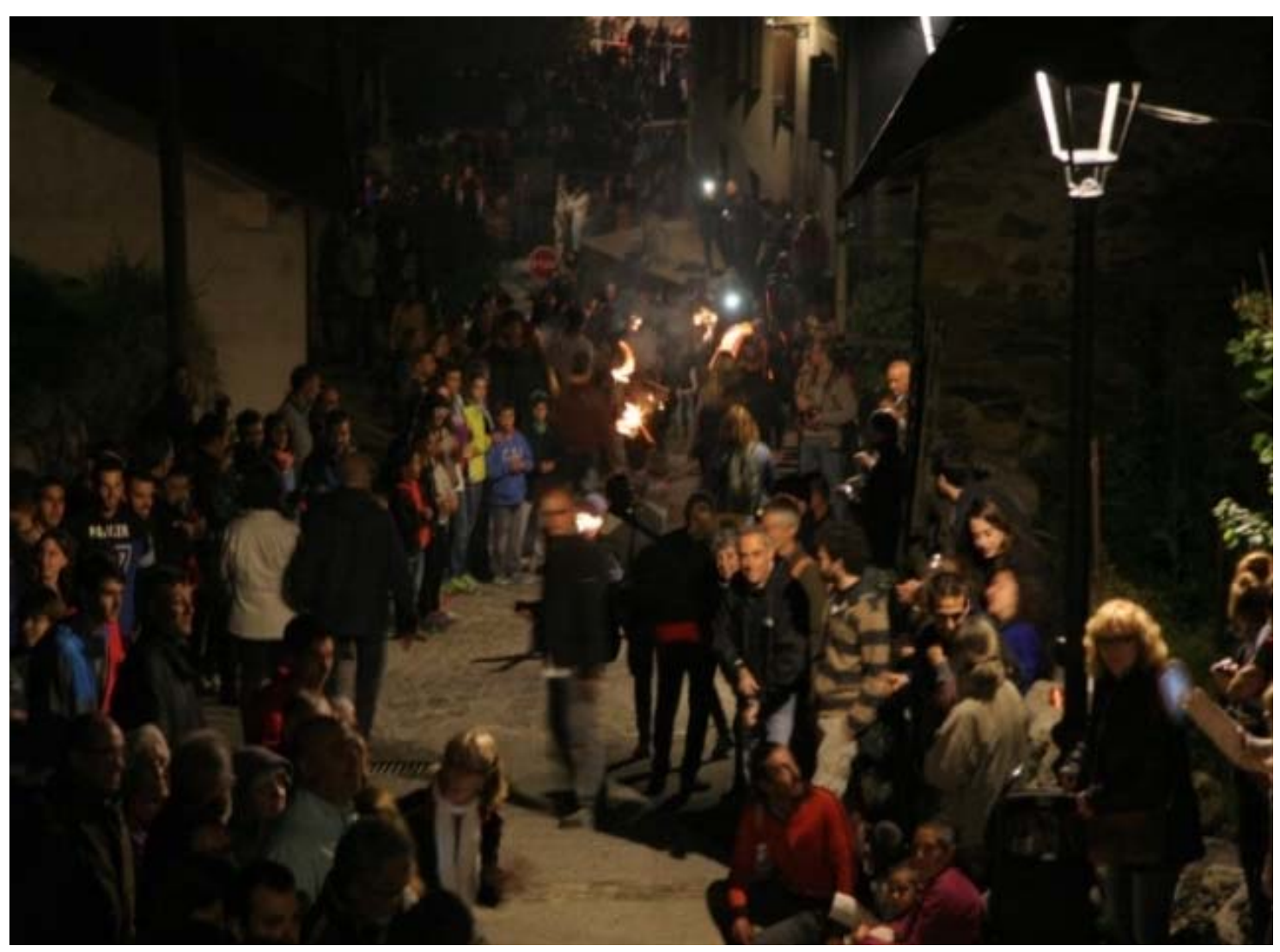

Fig 15. Fallas (where burning tree trunks are carried down the mountains). Source. A. F. Tulla

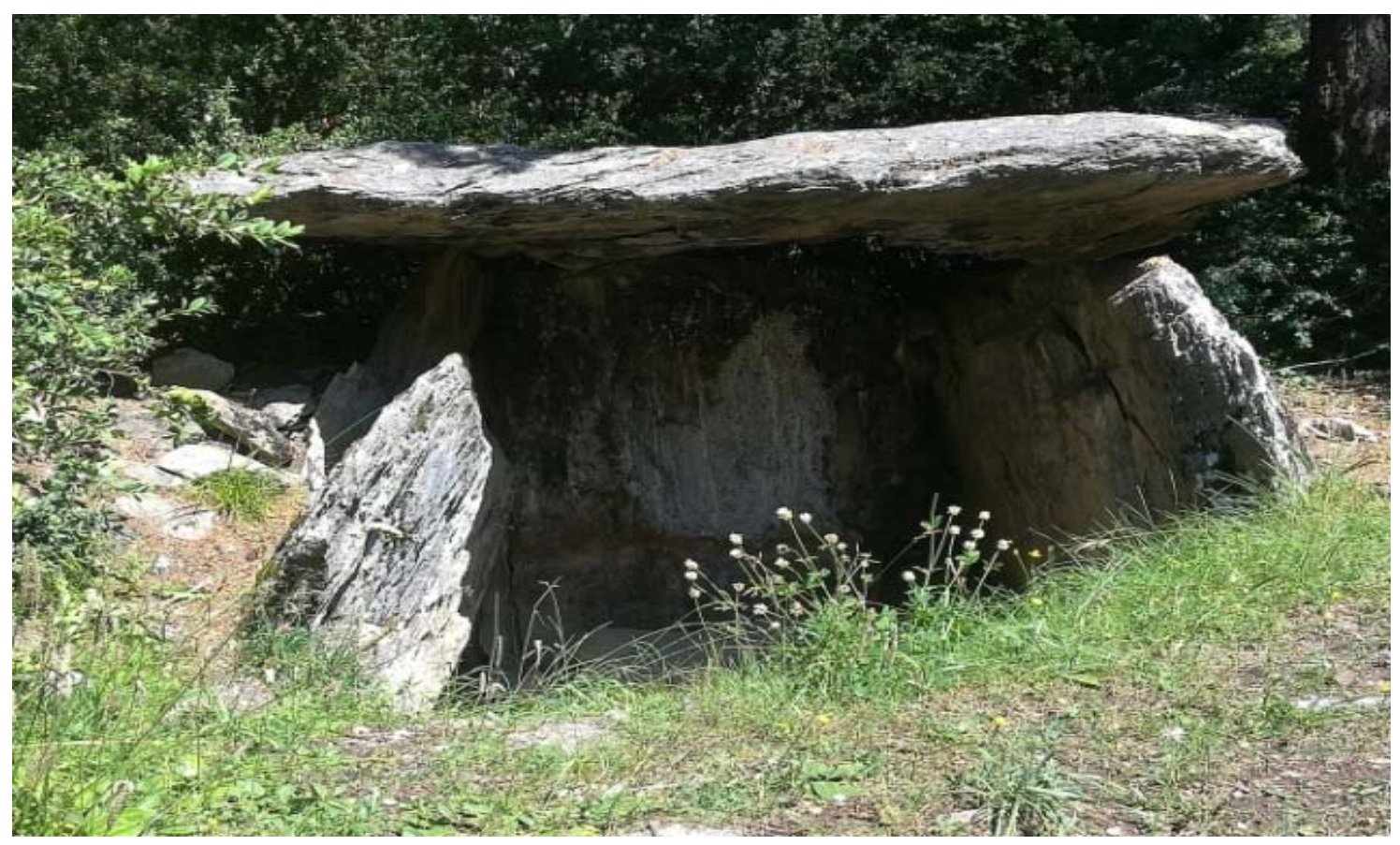

Fig 16. Dolmen. Source: A. F. Tulla

(5) Creation and maintenance of local and county museums (related with wool, wine, ice, etc.) The new museums or the restoration of buildings in order to revive and show old activities has been one of the most successful regional policies for increasing elements that help local development. 
(6) Social activities (pilgrimages, sports, village meetings, etc.). In each village or town there are other activities related with religion or hiking, among others, which ensure that a place will remain attractive for a long time.

(7) Hunting as a necessary and relational activity. In areas of low population density, the raiding of crops by certain animals such as boars has dramatically increased. Hunts, often organized by hunting societies, favor social relationships among inhabitants of rural areas and sometimes hunting parties are organized as a tourist attraction.

(8) Maintaining and promoting architectural heritage (identity, catalogue, record histories) with constructions like (a) churches, monasteries, shrines, hermitages, inter alia; (b) public buildings of different epochs (town halls, schools, bridges, castles, etc.); (c) architecture characteristic of the area (villages and rural masías - farm houses); and (d) farmyards, barns, stables and other buildings (see Figuress 16, 17 and 18).

(9) Considering rural landscape and protected natural areas (PNA) as heritage: (a) conservation and promotion; (b) environmental education; (c) bird watching, wildlife viewing (listening to deer in the mating season, for example) and looking at plants; (d) reconstruction and conservation of roads and tracks; (e) mountain shelters; ( $f$ ) youth hostels; $(g)$ green tourism and hiking; and (h) adventure tourism (canoeing, whitewater sports, canyoneering, climbing, etc.).

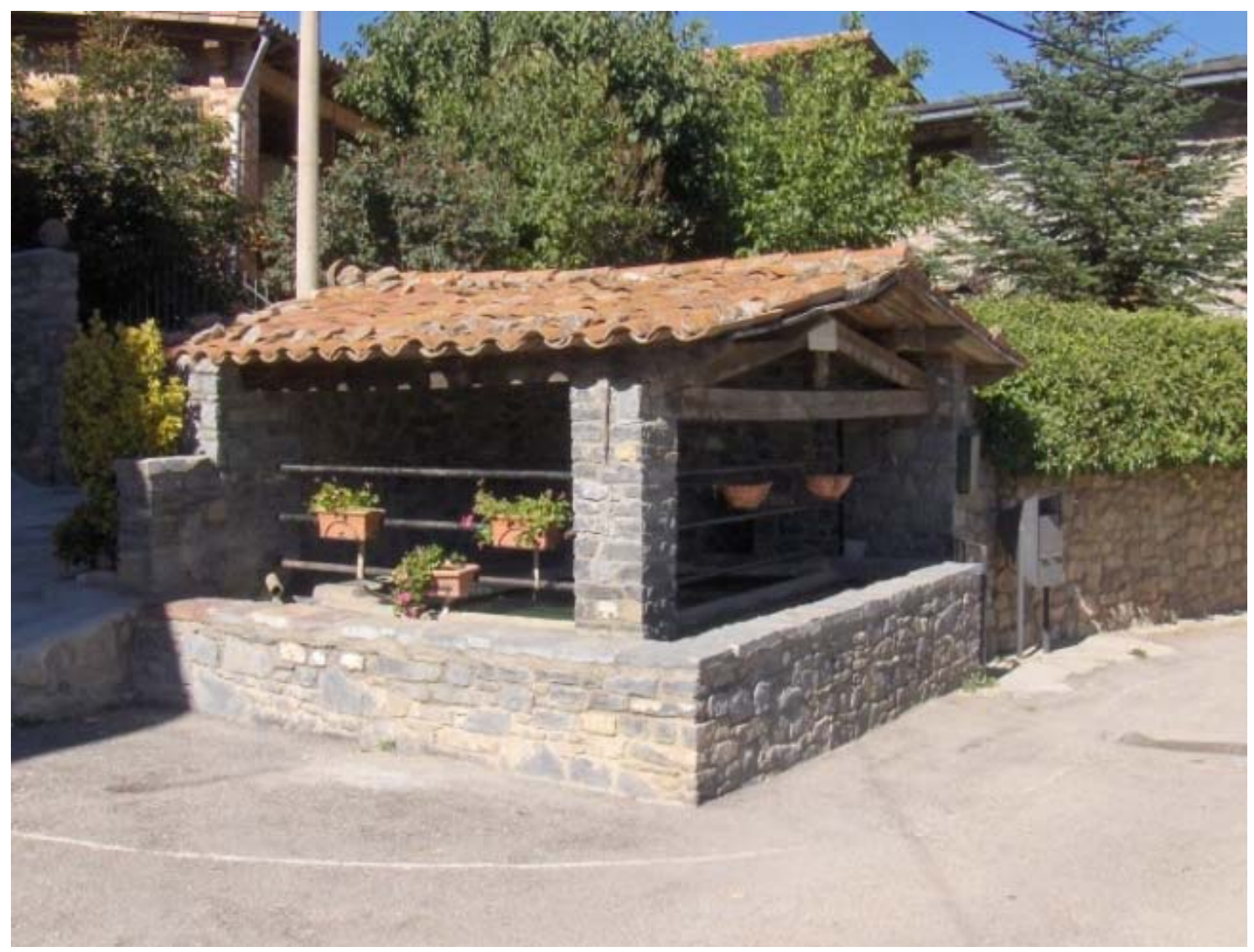

Fig 17. Old public laundry. Source: A. F. Tulla 


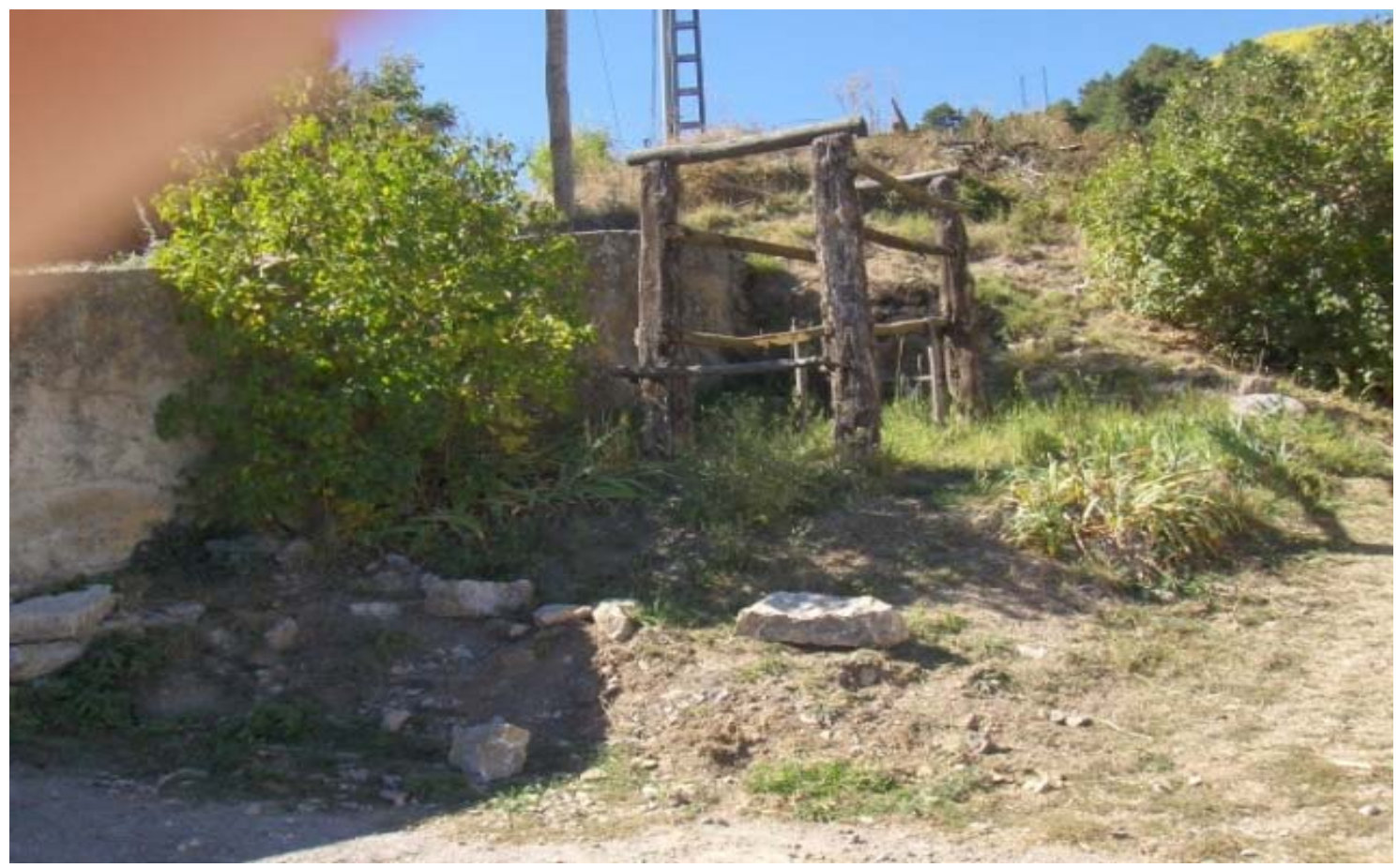

Fig 18. Crate for shoeing horses and draft animals. Source: A. F. Tulla

(10) Other activities that can generate added value include: (a) complementary tourist programs (electric bicycle, horseback riding, etc.), always respecting the environment and focusing on sustainability (so that future generations can make use of resources); (b) production of artisanal products made of wood and ceramics; (c) cultivation, selection and marketing of herbs and other plants to sell in the region and outside of it; (d) promotion and diffusion of "local brands" or "appellation of origin" that allow commercialization of agricultural, industrial or artisanal products; (e) industrial processing of quality food products, with the aim of selling them in cities and restaurants as semi-processed products; and (f) other activities and services (agritourism, alternative energy, information and communication techniques (ICT), etc) like positive naturbanization.

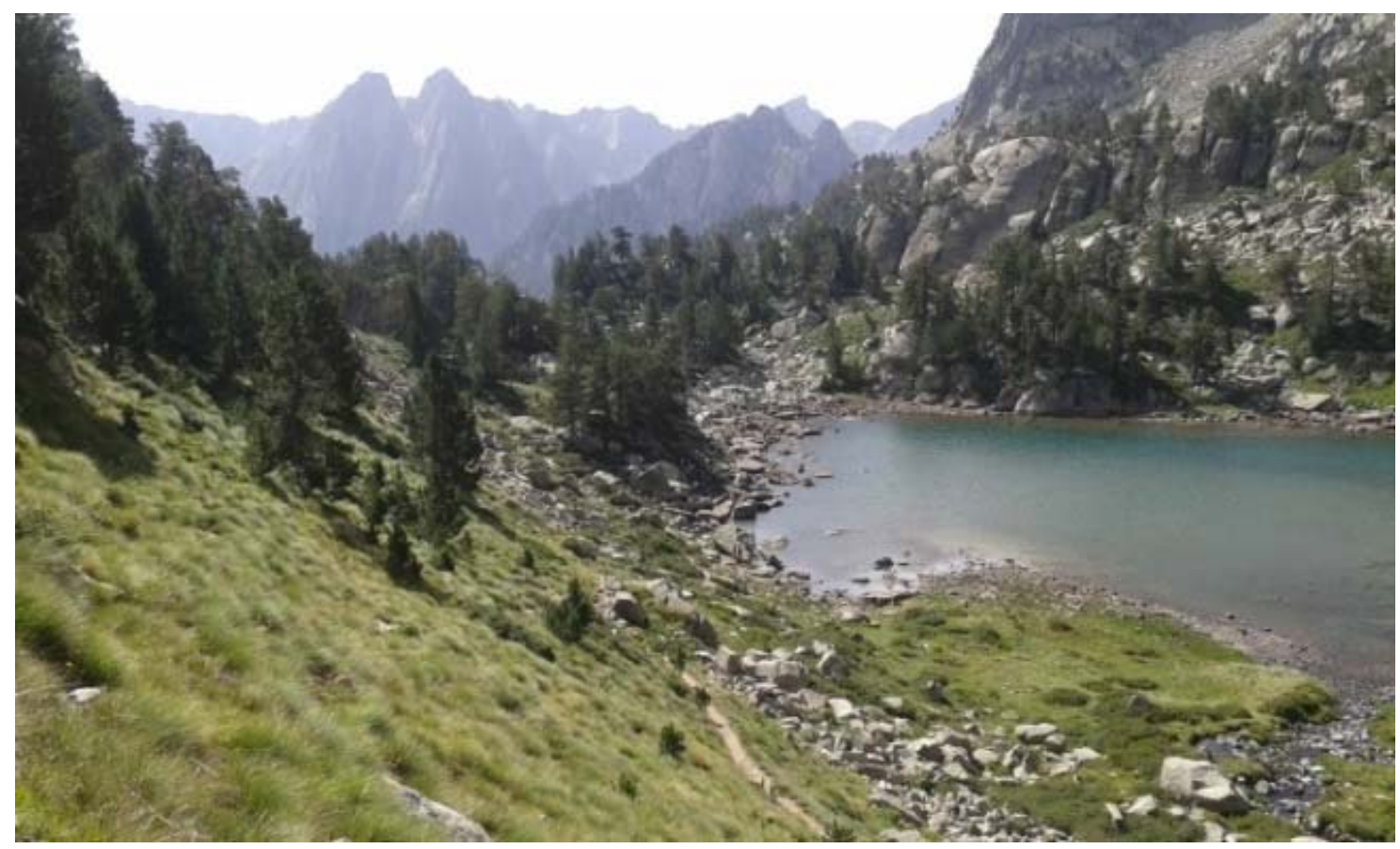

Fig 19. Natural landscape heritage. Source: A. F. Tulla 
The relationship between sustainable tourism and cultural heritage is increasingly evident (see Figures 19 and 20). On the one hand, the aim is to maintain and rehabilitate all the tangible and intangible elements of mountain regions in the economic and territorial periphery of urban systems. On the other hand, combination of the various economic activities of a place is needed in order to maintain the population of a territory. The activities must therefore provide the maximum possible added value as well as linking up with others. In cultural tourism, it is very important to establish this network of connections between the various elements of the heritage and social life of the mountain people.

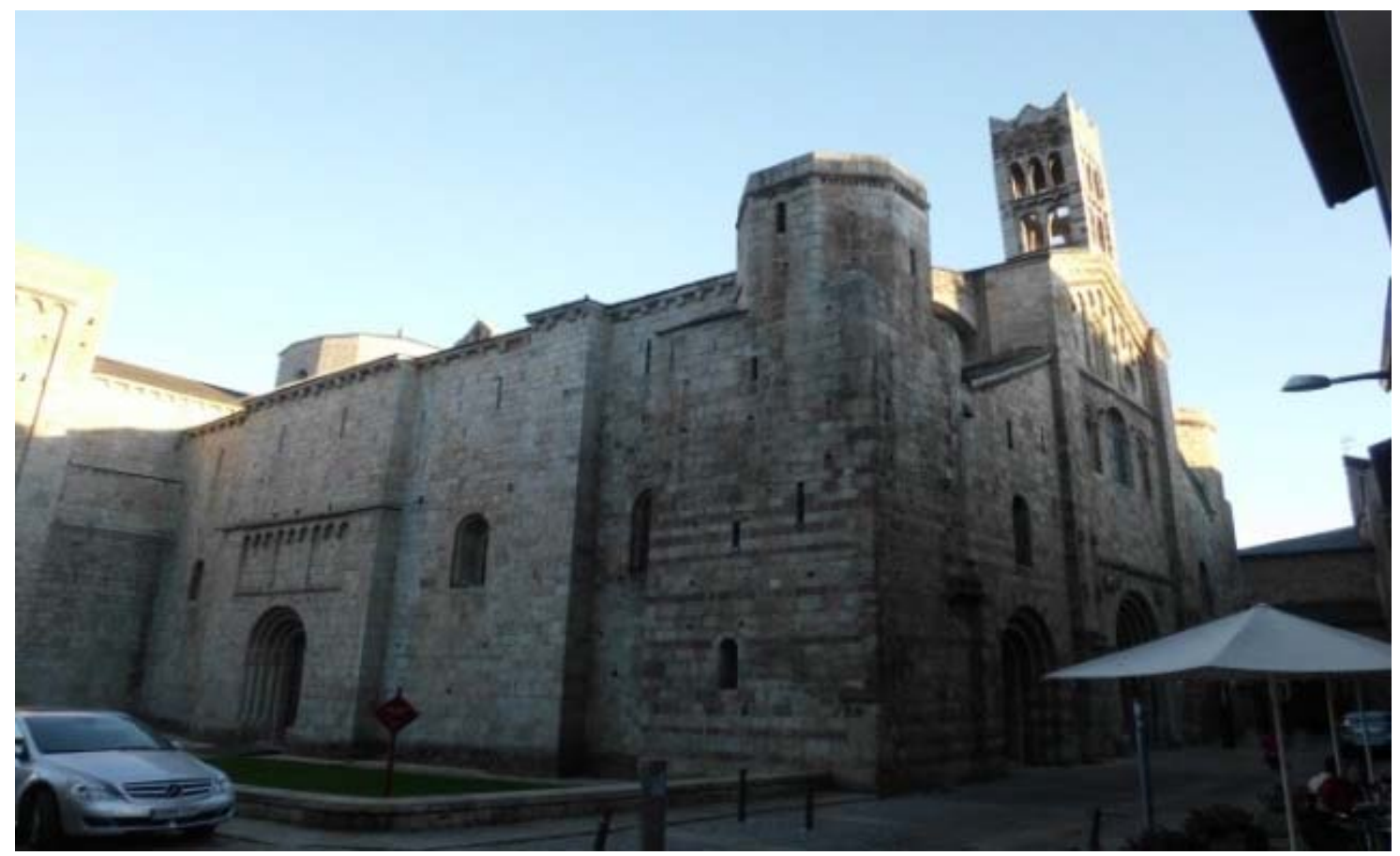

Fig 20. Architectural landscape heritage. Source: A. F. Tulla

\section{Discussion and conclusion}

The intensive agriculture of the so-called "Green Revolution" has marginalized many rural areas which have ended up being depopulated. Economic diversification in some of these areas since the 1980s, incorporating tourist activities and generating added value in agricultural products and other goods and services, has allowed their partial recovery with multi-functionality (Wood, 2011).

Value-added products, within the framework of the principle of comparative advantage when the second best option (SBO) method is applied, can help the economic and social recovery of peripheral regions like the Catalan Pyrenees. This approach is based on two assumptions. First, space is a scarce resource which means that decisions must be made about the best location for activities, and there is always another location where, although it may not be the optimal one, these activities can be located. Second, each region specializes in producing goods and services with a comparative advantage in relation to other regions. These advantages are assessed by natural resources or by location criteria, as well as by considering better use of intensive or extensive factors and the available resources.

In terms of the Theory of Comparative Advantage, peripheral regions may have possibilities for new economic locations when central areas become congested, but also because of the innovation and spatial loyalty of small and medium enterprises (SMEs). Each territory can develop activities or services, even if there are other territories that are better equipped for them, when these constitute the best specialization that can be carried out in the territory. For example, mountain apple trees have been recovered (Figure 21) for regional markets and old trails have been restored (Figure 22) to facilitate cycling, hiking and better accessibility to remote areas. 


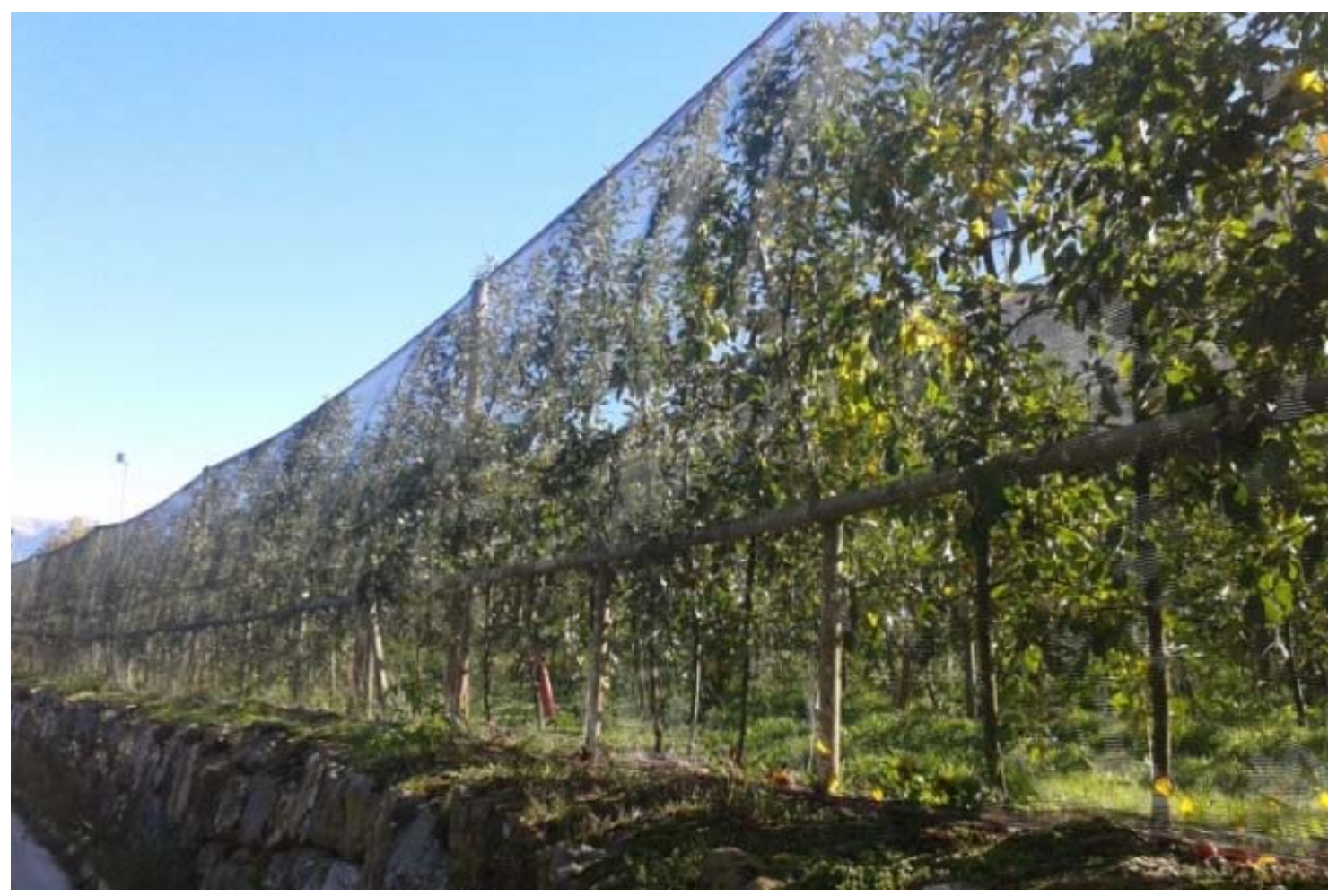

Fig 21. Cultivating mountain apple trees. Source: A. F. Tulla

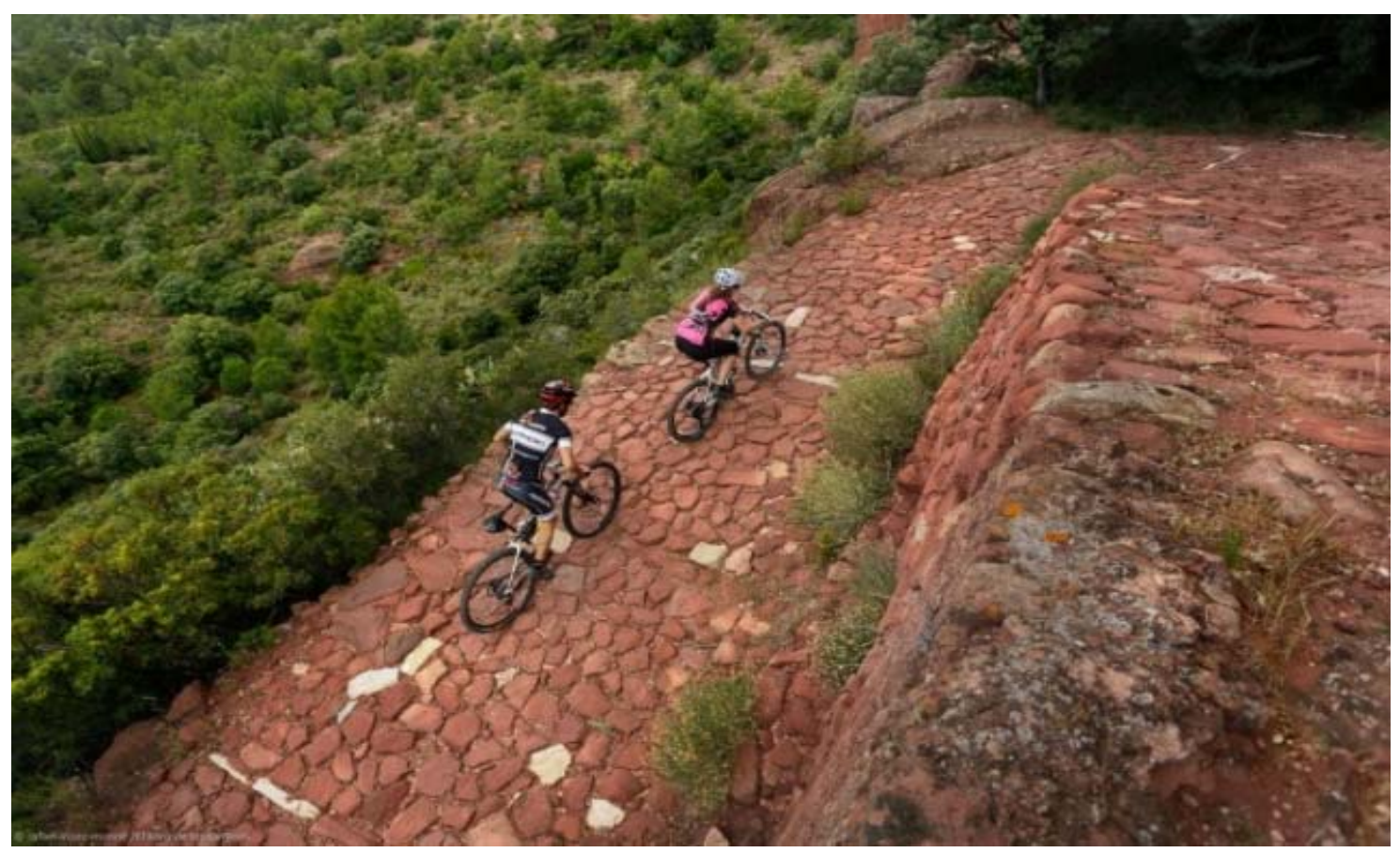

Fig 22. Restoring old trails. Source: R. López Monné

The dilemma between balanced development and polarization of unequal regional development suggests the possibility that some peripheral regions have a "relative comparative advantage" in terms of certain goods and services. Research projects carried out in the Catalan Pyrenees have demonstrated processing of dairy products, extensive ecological livestock farming for meat, tourist activities that respect the natural environment with offers including handicrafts, hiking or cross-country skiing, as well as cultural offers based on the historical, social and heritage wealth of the Pyrenees. 
On the basis of these four case studies, some "key elements" can be identified as indicators of how to make sustainable value-added activities possible:

- Identify the best area of specialization using the "second-best option method" and promoting economically viable value-added processes.

- Analyze possible ways of adapting traditional activities to new objectives.

- Develop programs of ecological (organic) agrarian activities.

- Promote innovation and joint projects with other sectors of the community.

- Support the human capital and social networks needed to strengthen spatial loyalty, and take into account women's initiatives which are open to ecological and social networks approaches.

- Encourage new cooperatives and other social initiatives to develop entrepreneurial projects.

- Conservation of protected natural areas helps to maintain biodiversity and favors the development of professional activities that use new technologies.

- Take advantage of regional loyalty and territorial roots of local business.

- Define public policies and programs to help develop local projects and initiatives.

Greater appreciation by consumers of the advantages of organic agriculture and proximity has favored the participation of farmers in local markets. At the same time, diminished employment opportunities in towns and cities have led young people to seek work in the countryside with the new organic production and "short commercial circuit". Social Farming activities are now appearing as an opportunity for organic agriculture with a social profile, this being based on the quality of its products and proximity to the consumer (farm to table) (Tulla et al., 2018).

Resilience appears as a dynamic social process, determined in part by the ability of many communities to deal with shared problems and act collectively. In this sense, CAP (Common Agricultural Policy) structural funds have considered three basic objectives since 1989: compensating for territorial imbalances by facilitating economic and social opportunities; correcting economic inequalities (gender and age, mainly); and protecting the environment by gradually implementing sustainability-based policies. These principles have contributed to the sustainable development of mountain areas and have facilitated the use of the SBO method within the framework of the Theory of Comparative Advantage.

\section{Acknowledgments}

Funding support from: CSO 2012-31979 (IP: A F Tulla), CSO2015-65257-R (IP: Anna Badia) and 2014 SGR-1090 (IP: M Pallarès-Barberà) projects is greatly appreciated.

\section{Academic references}

[1] Antoine, J.-M. \& Milian, J., eds. (2011). La Ressource Montagne. Entre potentialités et contraintes. Paris: Le Harmattan.

[2] Arcila Garrido, M. \& López Sánchez, J. A. (2015). Los centros de interpretación como motor de desarrollo local, ¿un modelo fracasado? El caso de la provincia de Cádiz. Boletín de la Asociación de Geógrafos Españoles, 67: 143-165 (471-473).

[3] Badia, A., Tulla, A. F. \& Vera, A. (2010). Los incendios em zonas de interfase urbano forestal. La integración de nuevos elementos en el diseño de la prevención. Scripta Nova, XIV, 331 (60).

[4] Barrachina, M. (2009) Landscape Change and Urbanization: A Case Study from Catalan Pyrenees. In: M. J. Prados, ed., Naturbanization: New identities and Processes for RuralNatural areas (167-181), London: Taylor and Francis. 
[5] Barrachina, M. \& Tulla, A. F. (2010). Els canvis socioambientals al Pirineu català: la Vall Fosca com a esceneri representatiu de les economies tradicionals de muntanya. Documents d'Anàlisi Geogràfica, 56(3): 557-572.

[6] Barrachina, M. (2011). Perspectives per a la ramaderia del Pirineu Català. Anàlisi multidimensional dels seus condicionants a partir de l'exemple de la Vall Fosca (Pallars Jussà). [Doctoral Thesis]. Universitat Autònoma de Barcelona.

[7] Barrachina, M., Serra-Diaz, J. M., Tulla, A. F. \& Cristóbal, J. (2012). On the Link between Socio-Economic Development and Landscape Changes in Two Pyrenean Valleys: The True Challenge of Multifunctionality. Environmental Engineering and Management Journal, 11(6), 1-7. DOI: 10.30638/eemj.2012.132.

[8] Barrachina, M., Cristobal, J. \& Tulla, A. F. (2015). Estimating Above-Ground Biomass on Mountain Meadows and Pastures through Remote Sensing. International Journal of Applied Earth Observation and Geoinformation, 38: 184-192. DOI: 10.1016/j.jag.2014.12.002.

[9] Baumgartner, D., Pütz, M. \& Seidl, I. (2013). What Kind of Entrepreneurship Drives Regional Development in European Non-Core Regions? A Literature Review on Empirical Entrepreneurship Research. European Planning Studies, 21(8), 1095-1127. DOI: 10.1080/09654313.2012.722937.

[10] Best, S. (1989). The Commodification of Reality and the Reality of Commodification: Jean Baudrillard and Post-Modernism. Current Perspectives in Social Theory, 19: 23-51.

[11] Bordons, G., ed. (2010). Manual de Gestió del Patrimoni Literari de l'Alt Pirineu i Aran, Tremp: Centre d'Art i Natura and Garsineu Edicions.

[12] Brown, D. L. \& Schucksmith, M. (2015). A New Lens for Examining Rural Change. European Countryside, 8 (2), 183. DOI: 10.1515/euco-2016-0015.

[13] Burandt, A. \& Mölder, T. (2017). Nature-Gender Relations within a Social-Ecological Perspective on European Multifunctional Agriculture: The Case of Agrobiodiversity. Agriculture and Human Values, 34: 955-967. DOI: 10.1007/s10460-016-9763-7.

[14] Capdepón Frías, M. (2015). The Role of Natural Parks in Tourism Diversification Processes: An Application to the Alicante Coastline. Cuadernos de Turismo, 35: 431-434.

[15] Copus, A. \& Hörnström, L. (2011). The New Rural Europe: Towards Rural Cohesion Policy. Stockholm: Nordic Centre for Spatial Development.

[16] Cuéllar, M., Calle, A. \& Gallar, D., eds. (2013). Procesos hacia la soberanía alimentaria. Perspectivas y prácticas desde la agroecología política. Barcelona: Icaria.

[17] Esparcia, J. (2014). Innovation and Networks in Rural Areas: An Analysis from European Innovative Projects. Journal of Rural Studies 34, 1-14. DOI: 10.1016/j.jrurstud.2013.12.004.

[18] Eychenne, C. (2008). Montagne versus haute montagne: Les recompositions territoriales du pastoralisme ariégeois. Sud-Ouest Européen 25, 39-49.

[19] Gosnell, H., Abrams, J. (2011). Amenity Migration: Diverse Conceptualization of Drivers, Socioeconomic Dimensions, and Emerging Challenges. GeoJournal, 76(4); 303-322. DOI: $10.1007 / \mathrm{s} 10708-009-9295-4$.

[20] Goulart Rocha, F., Tulla, A. F. (2015). Indicación geográfica de productos agrícolas: situación y perspectivas para la pequeña explotación familiar en Brasil. Documents d'Anàlisi Geogràfica, vol. 61/1: 67-89.

[21] Guinjoan, E., Badia, A. \& Tulla, A. F. (2016). The New Paradigm of Rural Development: Theoretical Considerations and Reconceptualization Using the 'Rural Web'. Boletín de la Asociación de Geógrafos Españoles, 71: 495-500. DOI: 10.21138/bage.2279.

[22] Hall, C. M. \& Lew, A. A. (1998). The Geography of Sustainable Tourism Development: An Introduction. In Hall, C. M. \& Lew, A. A. (eds.), Sustainable Tourism: A Geographical Perspective (pp. 1-12). Harlow: Longman. 
[23] Herslund, L. (2012). The Rural Creative Class: Counterurbanisation and Entrepreneurship in the Danish Countryside. Sociologia Ruralis, 52(2), 235-255. DOI: 10.1111/j.14679523.2011.00560.x.

[24] Horlings, L. G. \& Marsden, T. K. (2014). Exploring the 'New Rural Paradigm' in Europe: Ecoeconomic Strategies as a Counterforce to the Global Competitiveness Agenda. European Urban and Regional Studies, 21(1), 4-20. DOI: 10.1177/0969776412441934.

[25] Lipsey, R. G. \& Lancaster, K. (1956). The General Theory of Second Best. Review of Economic Studies, 24: 11-32.

[26] Lipsey, R. G. (2007). Reflections on the General Theory of Second Best at Its Golden Jubilee. International Tax and Public Finance, 14(4): 349-364. DOI: 10.1007/s10797-007-9036-x.

[27] Little, J., Ilbery, B., Watts, D., Gilg, A. \& Simpson, S. (2012). Regionalization and the Rescaling of Agro-food Governance: Case Study Evidence from Two English Regions. Political Geography, 31(2): 83-93. DOI: 10.1016/j.polgeo.2011.10.007.

[28] Mármol Cartañá, C. \& Gascón Chopo, C. (2016). Muntanyes de formatge. Transformacions productives i patrimonialització a l'Urgellet i el Baridà. Barcelona: Generalitat de Catalunya.

[29] Mendizabal, E., Ajenjo, M., Blanes, A. \& Sánchez, E. (1993). La población estacional en los municipios de Catalunya. Papers de demografia, 75.

[30] Milian, J. (2011). La protection de la nature, quelle ressource sociale pour la gestion et le développement des espaces montagnards? In Antoine, J-M. et Milian, J., eds., La ressource montagne. Entre potentialités et contraintes (pp. 249-272). Paris: Le Harmattan.

[31] Monllor, N. (2013). La nova pagesia: vers un nou model agrosocial. Quaderns Agraris, 35: 7-24. DOI: 10.2436/20.1503.01.25.

[32] Myrdal, G. (1957). Economic Theory and Under-Developed Regions. London: Gerald Duckworth and Co. Ltd.

[33] Navarro, F. A., Woods, M. \& Cejudo, E. (2016). The LEADER Initiative Has Been a Victim of Its Own Success. The Decline of the Bottom-Up Approach in Rural Development Programmes. The Cases of Wales and Andalusia. Sociologia Ruralis, 56(2), 270-288. DOI: 10.1111/soru.12079.

[34] Navarro, F. A., Cejudo, E. \& Cañete, J. A. (2018a). Análisis a largo plazo de las actuaciones en desarrollo rural neoendógeno. Continuidad de las empresas creadas con la ayuda de LEADER y PRODER en tres comarcas andaluzas en la década de los 90 del siglo XX. Ager. Journal of Depopulation and Rural Development Studies 25, 189-219. DOI: 10.4422/ager.2018.09.

[35] Navarro, F., Labianca, M., Cejudo, E., Rubertis, S., Salento, A., Maroto, J. C. \& Belliggiano, A. (2018b). Interpretations of Innovation in Rural Development. The Cases of LEADER Projects in Lecce (Italy) \& Granada (Spain) in 2007-13 Period. European Countryside, 10(1), 107-126. DOI: 10.2478/euco-2018-0007.

[36] Neumeier, S. (2017). Social Innovation in Rural Development: Identifying the Key Factors of Success. The Geographical Journal 183(1), 34-46. DOI: 10.1111/geoj.12180.

[37] Ohlin, B. (1933). Interregional and International Trade. Cambridge, MA: Harvard University Press.

[38] Olsen, E. (1971). International Trade, Theory and Regional Income Differences. Amsterdam: North-Holland.

[39] Pallarès-Barberà, M., Tulla, A. F. \& Vera, A. (2005). Spatial Loyalty and Territorial Embeddedness in the Multi-Sector Clustering of the Berguedà Region in Catalonia (Spain). Geoforum, 35(5), 635-649. DOI: 10.1016/j.geoforum.2004.03.004. 
[40] Pallarès-Blanch, M. (2012). Natural Protected Areas and Rural/Local Development: A Sustainable Strategy in Remote Areas. Urbani izziv, 23, supplement 2: 87-96. DOI: 10.5379/urbani-izziv-en-2012-23-supplement-2-0.

[41] Pallarès-Blanch, M., Tulla, A. F. \& Vera, A. (2013). Reintegración de un territorio entre fronteras: El Alto Segre, Pirineos. Geographicalia, 63-64: 121-156. DOI: $10.26754 /$ ojs_geoph/geoph.201363-64857.

[42] Pallarès-Blanch, M., Prados, M. J. \& Tulla, A. F. (2014). Naturbanization and Urban-Rural dynamics in Spain: Case Study of New Rural Landscapes in Andalusia and Catalonia. European Countryside, 6(2), 118-160. DOI: 10.2478/euco-2014-0008.

[43] Pallarès-Blanch, M., Tulla, A. F. \& Vera, A. (2015). Environmental Capital and Women's Entrepreneurship: A Sustainable Local Development Approach. Carpathian Journal of Earth and Environmental Sciences, 10(3), 133-146.

[44] Paniagua, A. (2002). Urban-Rural Migration, Tourism Entrepreneurs and Rural Restructuring in Spain. Tourism Geographies, 4(2), 349-371. DOI: 10.1080/14616680210158128.

[45] Prados, M. J. \& Vahí, A. (2012). A Territorial Analysis of the Agricultural Heritage in Andalusia: Case Studies of Rural Settlements and Hydraulic Systems for their Subsequent Enhancement. In Feria, J. M., ed., Territorial Heritage and Development (pp. 98-121). London: CRC Press.

[46] Peet, R. \& Hartwick, E. (1999). Theories of Development. New York: The Guilford Press.

[47] Ricardo, D. (1817). On the Principles of Political Economy and Taxation. Cambridge University Press.

[48] Roberts, L. \& Simpson, F. (2003). Encouraging Responsible Access to the Countryside. In Hall, D., Roberts, L. \& Mitchell, M., eds., New Directions in Rural Tourism (pp. 67-79). Aldershot: Ashgate Publishing Ltd.

[49] Servolin, C. (1972). L'ansortion de l'agriculture dans le mode de production capitaliste. In L'Univers politique des paysans. Paris; Armand Colin.

[50] Smith, D. M. (1977). Human Geography: A Welfare Approach. London: Edward Arnold.

[51] Smith, D. M. \& Lee, R., eds. (2004). Geographies and Moralities: International Perspectives on Justice, Development and Place. Oxford: Blackwell.

[52] Solé, A., Guirado, C. \& Solana, A. M. (2012). Cambios en la dinámica demográfica y migratoria del Pirineo catalán. Análisis sociolaboral de la población extranjera. AGER, Revista de estudios sobre despoblación y desarrollo rural, 12, 51-90. DOI: 10.4422/ager.2011.02.

[53] Sorensen, A. (2018). Conceptualising Rural Sustainability in an Era of Transformative Technologies and a Globalising World Economy. In Paül, V., Lois, R. C., Trillo, J. M. \& Haslam, F., eds., Infinite Rural Systems in a Finite Planet: Bridging Gaps towards Sustainability (pp. 140-145). Universidade de Santiago de Compostela.

[54] Stockdale, A. (2006). Migration: Pre-requisite for Rural Economic Regeneration? Journal of Rural Studies, 22(3), 354-366. DOI: 10.1016/j.jrurstud.2005.11.001.

[55] Thünen, J. H. von (1826). Der Isolierte Staat in Beziehung auf Laundwirtschaft und Nationalökonomie. Rostock.

[56] Throsby, D. (2001). Economics and Culture. Cambridge University Press.

[57] Timothy, D. J. (2011). Cultural Heritage and Tourism: An Introduction. Bristol: Channel View Publications.

[58] Tulla, A. F. (1993). Procés de transformació agrària en àrees rurals de muntanya: Lesexplotacions de producció lletera com a motor de canvi a les comarques de la Cerdanya, el Capcir, l'Alt Urgell i el Principat d'Andorra. Barcelona: Institut Cartogràfic de Catalunya. 
[59] Tulla, A. F., Pallarès-Barberà, M. \& Vera, A. (2009). Naturbanization and Local Development in the Mountain Areas of the Catalan Pyrenees. In: Prados, M. J., ed., Naturbanization: New Identities and Processes for Rural-Natural Areas (pp. 75-92). London: Taylor and Francis Group.

[60] Tulla, A. F., Stoica, I. V., Pallarès-Blanch, M. \& Zafir, D. (2017). Can Naturbanization Promote Environmentally Friendly Built-Up Areas? A Comparison between Cadí-Moixeró (Catalonia, Spain) and Comana (Romania) Natural Parks European Countryside, 9(4), 679-708. DOI: 10.1515/euco-2017-0039.

[61] Tulla, A. F., Vera, A., Valldeperas, N. \& Guirado, C. (2018). Social return and economic viability of social farming in Catalonia; A case - study analysis, European Countryside 10(3), 398-428. DOI: 10.2478/euco-2018-0023.

[62] Vera, A., Badia, A. \& Tulla, A. F. (2011). Desarrollo local en el Pirineo Catalán. Impulso económico y uso sostenible del territorio. Finisterra 46(92), 5-23. DOI: 10.18055/Finis1308.

[63] Viladomiu, L., Rosell, J. \& Francés, C. (2010). Factores determinantes de la participación de la mujer como promotores de proyectos LEADER. Revista Española de Estudios Agrosociales y Pesqueros, 226: 177-206.

[64] Wearing, S., Wearing, M. \& McDonald, M. (2012). Slow'n Down the Town to Let Nature Grow: Ecotourism, Social Justice and Sustainability. In Fullagar, S., Markwell, K. \& Wilson, E., eds., Slow Tourism: Experiences and Mobilities (pp. 36-50). Bristol: Chanel View Publications.

[65] Wight, P. (1998). Tools for Sustainability Analysis in Planning and Managing Tourism and Recreation in the Destination. In Hall, C. M. \& Lew, A. A., eds., Sustainable Tourism: A Geographical Perspective (pp. 75-91). Harlow (UK), Longman Ltd.

[66] Woods, M. (2011). Rural. London and New York: Routledge, Taylor and Francis Group.

[67] Zasada, I. (2011). Multifunctional Peri-Urban Agriculture - A Review of Societal Demands and the Provision of Goods and Services by Farming. Land Use Policy, 28(4), 639-648. DOI: 10.1016/j.landusepol.2011.01.008.

Other sources

[68] OCDE (2001). Multifunctionality: Towards an Analytical Framework, Paris: OECD. 